\title{
Monoclonal Antibodies: An Emerging Class of Therapeutics in Non Small Cell Lung Cancer
}

\author{
L. Guilleminault ${ }^{1,2,3}$, E. Lemarié ${ }^{1,2,3}$, N. Heuzé-Vourc'h ${ }^{1,2}$ \\ ${ }^{1}$ Université François Rabelais, Tours, France; ${ }^{2}$ Centre d'Etude des Pathologies Respiratoires, Tours, France; ${ }^{3}$ Service de Pneumologie, \\ Tours, France. \\ Email: guillel@free.fr
}

Received July $21^{\text {st }}, 2012$; revsied August $23^{\text {rd }}, 2012$; accepted September $2^{\text {nd }}, 2012$

\begin{abstract}
Lung cancer is the leading cause of cancer-related deaths in industrialized countries and non small cell lung cancer (NSCLC) accounts for $85 \%$ of all lung cancers. Cisplatin doublet based chemotherapy, which is the recommended regimen in first line therapy in advanced or metastatic NSCLC, improves survival but in low proportion. Monoclonal antibodies (mAbs) are a novel promising therapeutic class used with great results in inflammatory diseases such as rheumatoid arthritis. Antibodies are natural proteins with modular structure, specific pharmacodynamics and pharmacokinetics and possibly produced against any antigens, thus giving them several advantages over small drug therapeutics. In solid tumors, therapeutic mAbs improved progression free survival (PFS) and overall survival (OS) of patients with breast and colon cancers and had considerably changed the treatment in clinical practice. In NSCLC, bevacizumab, an anti-VEGF mAb, and cetuximab, an anti-EGFR mAb, are the most studied antibodies. Bevacizumab acts on angiognenesis and improved PFS of non squamous NSCLC but in low proportion as shown in two large phase III trials. It was approved by European Medicines Agency (EMEA) and Food and Drug administration (FDA) as a first line therapy in combination with cisplatin doublet chemotherapy. Cetuximab slightly enhanced OS but did not improve PFS in two large phase III trials. These results added to high adverse effect lead to cetuximab refusal by EMEA and FDA in NSCLC. At first glance, the results of mAbs in NSCLC are somewhat disappointing, in contrast to the benefits obtained with $\mathrm{mAb}$ treatments in other solid tumors. However, many other mAbs directed against novel targets, such as IGF1-R or CTLA-4, and new mAbs targeting VEGFR and EGFR pathways with different pharmacodymamical and pharmacokinetic properties are under evaluation and may change our vision of taking care of patients with NSCLC. In conclusion, it seems that mAbs therapy in NSCLC clearly marks the start of a new era in NSCLC treatment, with promises in improving patient survival and quality of life.
\end{abstract}

Keywords: Monoclonal Antibody; Targeted Therapy; Non Small Cell Lung Cancer; Immunoglobulin

\section{Introduction}

Cytotoxic agents and radiation therapy have been used to improve the survival and quality of life of patients with cancer, but they no longer increase patient survival and yield many side effects. The past few decades have seen huge progress in our understanding of the molecular mechanisms underlying tumor development and dissemination, and this has led to the development of specific therapies with reduced systemic toxicity and improved patient survival. Targeted therapies include smallmolecule kinase inhibitors and biotherapeutics, including monoclonal antibodies $(\mathrm{mAb})$. Antibodies have become major biodrugs for treating solid and hematological tumors. They are natural proteins that bind to one of a huge variety of molecular targets with great specificity. Their structure is multimodular, and each domain has a well- defined function. Therapeutic mAbs are not only specific, they also have pharmacodynamical and pharmacokinetic advantages over small molecule drugs, together with limited toxicity. This is why therapeutic mAbs are one of the fastest growing areas of the pharmacological/biotechnological industry, with applications in oncology, in immune and inflammatory disorders. Six therapeutic mAbs have now been approved by the US Food and Drug Administration (FDA) for treating solid tumors, whereas only one was available ten years ago.

Lung cancer is the leading cause of cancer fatalities in industrialized countries and non small cell lung cancer (NSCLC) accounts for $85 \%$ of all lung cancers [1]. The American Society of Clinical Oncology recommends cisplatin doublet based chemotherapy as the first-line treatment for NSCLC, but the increase in median survival time is modest [2]. Spiro et al. showed that the me- 
dian survival time of patients with advanced NSCLC treated with cisplatin doublet based chemotherapy (8 months) was only 9 weeks longer than for patients given the best supportive care (5.7 months) [3]. Treatment with mAbs has greatly prolonged the survival of patients with solid tumors like breast and colon cancers $[4,5]$. They are therefore providing hope to patients with metastatic or locally advanced NSCLC who cannot be treated by surgery. Only one therapeutic antibody, bevacizumab targeting VEGF, is presently approved for treating NSCLC, but several others are under clinical investigation and may improve the survival and quality of life of NSCLC patients. The first part of this chapter summarizes the characteristics of therapeutic antibodies while the second part discusses clinical trials of mAbs designed to treat NSCLC.

\section{Therapeutic Antibodies in Cancer: Rationale}

Most monoclonal antibodies (mAb) used as therapeutics are full length IgGs, often of the IgG1 or IgG3 subclasses. They have a molecular weight of $\sim 150 \mathrm{kDa}$ and a valence of 2, which means that each molecule can bind two identical epitopes of the antigen. IgGs are composed of a Fab domain (fragment of antigen binding) containing the antigen binding site region, and an $\mathrm{Fc}$ region corresponding to the effector domain [6].

Paul Erhlich was the first to consider antibodies as therapeutics in his "magic bullet" theory in 1908 [7]. Achievement of this concept became possible with the development of mouse hybridoma technology by Köhler and Milstein, the first reliable source of monoclonal antibodies [8]. Despite the fact that they had overcome major technological problems, mouse $\mathrm{mAb}$ were disappointed in clinical studies. This was because the mouse $\mathrm{mAb}$ that were used had a short half-life in human serum and triggered immune responses in human subjects that limited the possibilites of repeated injections $[9,10]$.

The human anti-mouse antibody responses (HAMA) was reduced by engineering mAbs that lacked most of the murine sequences, leading to chimeric $\mathrm{mAbs}$ and humanized mAbs [11-13]. In terms of immunogenicity, Hwang and Foote reported a significant decrease in marked anti-antibody response (AAR) when the Fc regions of murine mAbs were replaced with human sequences [14]. More recently, fully human mAbs have also been produced by transgenic animals or phage display technology and they are being used more and more in clinical trials. However, the improved safety of humanized and fully human mAbs in clinics is still being debated [10]. Getts et al. recently reviewed the clinical data for 38 human(ized) and 43 rodent-derived antibodies with contrasting indications and suggest that both types of mAbs trigger similar acute phase reactions and infusion reactions.

Therapeutic antibodies differ from small molecule drugs in their pharmacological properties. The mechanisms by which therapeutic mAbs act depend on their $\mathrm{Fab}$ and/or Fc domains and/or the cytotoxic agents conjugated to them (for summary, see Table 1). Therapeutic mAbs bind to their antigen through the Fab domain, usually with high affinity, specificity and selectivity [13]. Therapeutic antibodies may also act through their Fc domains that enable an antibody to interact with molecules such as complement or Fc receptors $[15,16]$. Indeed, an IgG bound to its target antigen can be recognized by specific Fc-receptors, Fc $\gamma$ Rs, which in turn can lead to the recruitment of immune cells effectors, such as natural killer (NK) cells, granulocytes, monocytes or macrophages. This cascade leads to phagocytosis and antibody-dependent cellular cytotoxicity (ADCC) [17]. After interacting with its antigen, $\mathrm{mAb}$ can also activate the complement system, leading to complement-dependent cytotoxicity (CDC) [16]. Most of the approved mAb can induce $\mathrm{CDC}$ in vitro, but the clinical relevance of this function remained unclear for a long time, with only indirect presumptions.

Therapeutic mAbs, in particular anticancer mAbs, may also act through a conjugated cytotoxic agent, such as radioisotopes and small chemotherapeutic molecules [18]. In this case, the mAb acts as a delivery vehicle, carrying the cytotoxic drug to the therapeutic site.

Monoclonal antibodies have other advantages over small (non-biological) molecules. First, their range of targets is almost limitless. Second, they are unlikely to have unexpected side-effects $[19,20]$. Their high selectivity reduces the potential of non-mechanism-based toxicity and their bioconversion is well-defined. Antibodies are metabolized to non-toxic peptides and amino acids by circulating phagocytic cells or by their target cells. Thera-

Table 1. Multi-faceted activity of therapeutic mAbs.

\begin{tabular}{|c|}
\hline Mechanisms of action \\
\hline $\begin{array}{l}\quad \text { Naked antibody- direct effects } \\
\text { - }\end{array}$ \\
\hline $\begin{array}{l}\text { Naked antibody-indirect effects } \\
\text { - } \quad \text { Antibody-dependent cellular cytotoxicity (ADCC) } \\
\text { - Complement-dependent cytotoxicity (CDC) }\end{array}$ \\
\hline $\begin{array}{l}\text { Armed antibody } \\
\text { - } \quad \begin{array}{l}\text { Delivery of cytotoxic molecules } \\
\text { (radionuclides, small chemotherapeutic drugs, toxins...) }\end{array} \\
\text { - } \quad \text { Immunomodulation (cytokine) }\end{array}$ \\
\hline
\end{tabular}


peutic mAbs are generally safe $[19,20]$. Hence, preclinical and clinical trials tend to be very successful. The tox icity of mAbs is mainly associated with excessive pharmacological activity and/or the presence of the targeted antigen in tissues where the therapeutic effect is useless [20]. Serious adverse effects of mAbs include anaphylaxis, a rare response to the first infusion (IgE-mediated), and the cytokine release syndrome (CRS) or cytokine storm [21].

Last, therapeutic antibodies differ from small molecule drugs in their pharmacokinetic (PK) profiles. The PK describes the outcome of injecting mAbs into the human body and is a critical parameter in describing their clinical actions. Various factors may contribute to the removal of a mAb, including the amount of the target antigen, immune reactions to the antibody, the delivery route and patient characteristics [22]. One of these factors, the $\mathrm{FcRn}$ receptor, plays a critical role regulating $\mathrm{mAb}$ pharmacokinetics [23]. Indeed, the FcRn protect IgGs from catabolism and mediates the transport of IgG across epithelial/endothelial cells [23]. It therefore plays a central role in the absorption and distribution of mAbs from the bloodstream to the tissues, and strongly influences their half-life in biological fluids [23].

Smaller structures derived from IgGs, containing an antigen binding domain ( $\mathrm{Fab}$ ) or a single chain variable fragment $(\mathrm{scFv})$, have also been engineered. Their pharmacokinetics, distributions and pharmacological properties are different from those of intact IgGs [24].

A total of 30 monoclonal antibodies and three fragments are presently approved for sale around the world for treating human diseases and there are nearly 350 candidate $\mathrm{mAbs}$ in the pipeline. Several have achieved "blockbuster" status, with annual sales of over $\$ 1$ billion. The majority of mAbs on the market or in clinical development are approved or evaluated as treatments for cancer or immunological diseases. Other indications include infectious and central nervous system diseases [25].

Due to advantages cited above, therapeutic antibodies are a hopefull potential therapy in NSCLC. Antibodies, which were or are currently evaluated in NSCLC, are detailed further.

\section{Therapeutic Antibodies and Angiogenesis}

\subsection{Anti-VEGF Antibodies}

Angiognesis has been known to play a role in cancer pathophysiology for over a century [26]. VEGF (also called VEGF A) is involved in angiogenesis and interacts with two related receptors, tyrosine kinase VEGFR-1 and VEGFR-2 [26]. These receptors are present on endothelial cells and hematopoietic cells, and are autophosphorylated once VEGF bound to them [26].
In NSCLC, overproduction of VEGF is associated with tumor progression and poor prognosis [27,28]. A recent meta-analysis showed that VEGF overproduction in NSCLC, assessed by immunohistochemistry, is associated with poor prognosis with a hazard ratio of 1.46 [29]. The high concentrations of VEGF in NSCLC led to the proposal of anti-VEGF antibody, as potential cancer treatments.

\subsection{Bevacizumab: Current Concept}

Bevacizumab is a recombinant humanized IgG1 directed against soluble VEGF [30]. In NSCLC, safety clinical trials showed that most adverse events observed with association of bevacizumab-chemotherapy were HTA, proteinuria, pulmonary hemorrhage and thrombosis [3135]. Grade $\geq 3$ HTA ranged from $0 \%$ to $16.7 \%$, grade $\geq 3$ proteinuria $0 \%$ to $3.2 \%$ and grade $\geq 3$ thrombosis $5 \%$ to $14.7 \%$ [31-35]. Grade $\geq 3$ Pulmonary hemorrhage ranged from $2 \%$ to $9.4 \%$ and was the most severe toxicity with significant grade 5 events $[31,36]$. Overall, bevacizumab was well tolerated in adenocarcinoma. Fatal pulmonary hemorrhages occured almost exclusively in squamous carcinoma [31], and led to exclusion for a long time of this histology from clinical trials. However, the recent BRIDGE study, conducted by Hainsworth et al., showed that pulmonary hemorrhage was low in squamous carcinoma patients with no history of pulmonary haemorrhage [32].

Bevacizumab was approved by the Food and Drug Administration (FDA) as a first-line therapy for advanced or recurrent NSCLC without predominantly squamous cell histology in 2006. It was based on the results of the ECOG 4599 and AVAiL (Avastin in Lung) trials $[37,38]$. In both trials, bevacizumab was given together with chemotherapy to patients with advanced or recurrent non-small cell lung cancer. Bevacizumab treatment was given every 2 weeks and continued until the disease progressed. The chemotherapy was cisplatin plus gemcitabine in the European trial (AVAiL), while it was carboplatin plus paclitaxel in the American trial (ECOG 4599) $[37,38]$. In the ECOG and AVAiL trials, the median overall survival (OS) and progression free survival of the group given chemotherapy plus bevacizumab was significantly longer than patients given chemotherapy alone (Table 2) [37]. In AVAil trial, two doses of bevacizumab were tested $7.5 \mathrm{mg} / \mathrm{kg}$ and $15 \mathrm{mg} / \mathrm{kg}$ [38]. The progression-free survival time was significantly longer in the two groups treated with bevacizumab than for the chemotherapy alone patients with no difference between both dosages (Table 2). The follow-up was too short for overall survival (OS) analysis, but median survival times were unusually long, over 13 months, for all three patient groups. 
Table 2. Phase III and IV clinical trials of bevacizumab combined with chemotherapy as first or second line therapy in NSCLC. PC: Paclitaxel/Carboplatin, Cis/Gem: Cisplatin/Gemcitabine. PFS: progression free survival. OS: overall survival. PH: pulmonary hemorrhage.

\begin{tabular}{|c|c|c|c|c|}
\hline Authors & Drugs & Patients & Response rate & Grade $\geq 3$ toxicity \\
\hline Phase III [37] & $\begin{array}{l}\text { Arm A: Bevacizumab } 15 \\
\mathrm{mg} / \mathrm{kg}+\mathrm{PC} \\
\text { Arm B: PC alone }\end{array}$ & $\mathrm{n}=818$ & $\begin{array}{c}\text { PFS: Arm } A=12.3 \text { months } \\
\text { Arm } B=10.3 \text { months } \\
\text { OS: Arm A }=6.2 \text { months } \\
\text { Arm B }=4.5 \text { months }\end{array}$ & $\begin{array}{l}\text { HTA: } 7 \% \\
\text { Proteinuria: } 3.1 \% \\
\text { PH: } 1.9 \%\end{array}$ \\
\hline Phase III [38] & $\begin{array}{c}\text { Arm A: Cis/Gem alone } \\
\text { Arm B: Bevacizumab } 7.5 \\
\text { mg/kg + Cis/Gem } \\
\text { Arm C: Bevacizumab } 15 \\
\text { mg/kg + Cis } / \text { Gem }\end{array}$ & $\mathrm{n}=1043$ & $\begin{aligned} & \text { PFS: } \text { Arm } A=6.7 \text { months } \\
& \text { Arm } B=6.5 \text { months } \\
& \text { Arm } C=6.1 \text { months } \\
& \text { No sufficient data for OS analysis }\end{aligned}$ & $\begin{array}{l}\text { HTA: } 6 \%(\mathrm{~A}), 9 \%(\mathrm{~B}) \\
\text { Bleeding: } 4 \%(\mathrm{~A}), 4 \%(\mathrm{~B}) \\
\text { Proteinuria: }<1 \%, 1 \% \\
\text { PH: } 1.5 \%(4 / 5 \text { grade } 5)(\mathrm{A}) \\
0.9 \%(\text { all grade } 5)(\mathrm{B})\end{array}$ \\
\hline Phase IV [39] & $\begin{array}{l}\text { Various chemotherapy } \\
\text { regimen }+ \text { Bevacizumab }\end{array}$ & $\mathrm{n}=2212$ & & $\begin{array}{l}\text { PH: } 1 \% \\
\text { HTA: } 6 \% \\
\text { Proteinuria: } 3 \% \\
\text { Thrombosis: } 8 \%\end{array}$ \\
\hline
\end{tabular}

The final approval of bevacizumab by the FDA and EMEA required a phase IV study to assess its safety in "real life" with unselected patients. In agreement with safety clinical trials, the incidence of clinically significant (grade $\geq 3$ ) adverse events of special interest with bevacizumab $(7.5$ or $15 \mathrm{mg} / \mathrm{kg}$ ) was generally low in the SAiL study [39]. Thromboembolism occurred in $8 \%$, hypertension in $6 \%$, bleeding in $4 \%$, proteinuria in $3 \%$ and pulmonary haemorrhage in $1 \%$. Three percent died because of adverse events [39].

The profile of bevacizumab in patients 70 years of age or older was also a crucial question because elderly patients with an NSCLC are no longer uncommon considering the increase in life expectancy. Data obtained from subgroup analysis of ECOG 4599, AVAiL and SAiL studies showed a low benefit of bevacizumab compare to chemotherapy alone in elderly, with efficacy and safety profile of bevacizumab somewhat similar to young patients [40-42]. However, this result was not confirmed in a recent retrospective study of 4168 Medicare benificiaries aged from 65 years old and older [43].

\subsection{Bevacizumab: Future Direction}

\subsubsection{Maintenance Therapy}

Maintenance therapy is defined as therapy that is continued without a break after the end of first line therapy. Bevacizumab is, by definition, a maintenance therapy because it is given in NSCLC until disease progression. Bevacizumab combined with maintenance therapy (pemetrexed) is currently under evaluation in various clinical trials [44-48]. Preliminary results of AVAPERL trial showed better PFS (10.2 months) with pemetrexed/bevacizumab than bevacizumab maintenance (6.6 months) [48].

\subsubsection{Targeted Therapy}

Erlotinib is a HER-1/epidermal growth factor receptor tyrosine kinase inhibitor (TKI) that improves the survival time of patients with advanced NSCLC who have been given one or two prior chemotherapy regimens [49]. In theory, administering bevacizumab and erlotinib together may have additional clinical benefits because bevacizumab and erlotinib act on two different pathways. Combination of bevacizumab and erlotinib was well tolerated in clinical trials but did not improve OS (Table 3) [50-53]. The recent phase III trial ATLAS, assessing bevacizumab and erlotinib met its primary endpoint with a significant $(28 \%)$ decrease in the risk of progression and an increase in the median PFS of 1.1 months comparing with erlotinib alone [54]. Data on overall survival have not yet been presented and are awaited with great interest.

\subsubsection{Predictive Markers}

Despite the benefit of bevacizumab in clinical studies, some patients do not response to this therapy. The greatest challenge in using bevacizumab to treat patients with NSCLC is to identify predictive biomarkers that may help discriminate patients most likely to respond to it. In metastatic colorectal cancer, Jubb et al. showed that adding bevacizumab to chemotherapy improved survival regardless the concentration of VEGF or thrombospondin-2, or the microvessel density [55]. In NSCLC, the ECOG 4599 trial reported that the baseline ICAM concentrations were prognostic for survival and predicted the response to chemotherapy with or without bevacizumab [56]. VEGF concentrations predicted only the response to bevacizumab but not survival. Overall, high blood pressure (>15/10) (HBP) by the end of first cycle may be the most reliable predictive marker. It was demonstrated that patients with HBP had better OS and PFS when they were treated with bevacizumab [57]. At the present time, bevacizumab is still given to NSCLC patients with no 
selection and further studies are needed.

\subsection{Other Antiangiogenic mAbs}

In preclinical studies, ramucirumab, an antibody directed specifically against VEGFR-2, was combined with radiotherapy with interesting results [58]. In NSCLC patients, it is currently tested in phase II trial in combination with chemotherapy $[59,60]$. It is also tested in a phase III trial on NSCLC patients previously treated as second line therapy in combination with docetaxel [61]. This trial is still recruiting participants.Bavituximab is a vascular targeting antibody directed against phosphatidylserine which is restricted to the internal surface of the endothelial cell membrane [62]. In NSCLC, preliminary results with bavituximab combined with chemotherapy, showed an overall response rate of $52.4 \%$, with a clinical complete response in $4.8 \%$ and a partial response in $47.6 \%$ [63]. The median progression-free survival time was 6.2 month. Two phase II trials have been set up, one to compare carboplatin/paclitaxel to carboplatin/paclitaxel/ bavituximab in chemonaive NSCLC patients and the other one to compare docetaxel with docetaxel/bavituximab in previously treated NSCLC patients $[64,65]$. The primary endpoint for both studies is the objective response rate.

\section{Anti-HER Antibodies}

The epidermal growth factor (EGFR) family of molecules is a subclass I of the receptor tyrosine kinase (RTK) superfamily and has four members: EGFR, HER2, HER 3 and
HER 4 [66]. EGFR is overexpressed in NSCLC and tumor cells produce the EGFR ligands which can activate cell surface receptor $[67,68]$. However, overproduction of EGFR does not seem to be associated with a poor prognosis in NSCLC, unlikely in other cancers [67]. Although HER2 does not interact with EGF-like ligands, it is the preferred heterodimer partner of the other three receptors [69]. HER2 is infrequently overproduced in NSCLC, but it seems to be associated with a poor prognosis [70]. HER2 overexpression in NSCLC ranges from $7 \%$ to $23 \%$ by immunohistochemistry and $2 \%$ to $23 \%$ by FISH [70-74].

\subsection{Cetuximab: Current Concept}

Cetuximab is an IgG1 mAb that targets EGFR and competitively inhibits endogenous ligand binding [75]. In NSCLC clinical trials, safety of cetuximab was over-all acceptable. The most reported adverse effects were skin rash and neutropenia [76-82]. Grade $\geq 3$ skin rash ranged from $0 \%$ to $28 \%$. [76,79] Grade $\geq 3$ neutropenia was dependent on chemotherapy regimen used. It ranged from $0 \%$ to $44 \%[81,82]$. Allergic reaction was reported in some trials $[78,83]$ but was less common than in head and neck cancer patients. A recent meta-analysis estimated that cetuximab was associated with a higher incidence of hypomagnesemia (5.6\%) compared with chemotherapy alone [84]. Despite this well tolerated profile, cetuximab did not improve PFS in phase III FLEX and BMS099 clinical trials [75,86] (Table 4). In these studies,

Table 3. Phase III clinical trial of bevacizumab combined with erlotinib. PFS: progression free survival. OS: overall survival.

\begin{tabular}{|c|c|c|c|c|}
\hline Authors & Drugs & Patients & Response rate & Toxicity \\
\hline Phase III [50] & $\begin{array}{l}\text { Arm A: Bevacizumab } 15 \mathrm{mg} / \mathrm{kg}+ \\
\text { Erlotinib } \\
\text { Arm B: Erlotinib alone }\left(2^{\text {nd }} \text { line }\right)\end{array}$ & $\mathrm{n}=636$ & $\begin{array}{r}\text { PFS: } \text { Arm } \mathrm{A}=3.4 \text { months } \\
\text { Arm } B=1.7 \text { months } \\
\text { OS: Arm A }=9.2 \text { months } \\
\text { Arm B }=9.3 \text { months }\end{array}$ & Similar between group \\
\hline
\end{tabular}

Table 4. Phase III clinical trials of cetuximab alone or combined with chemotherapy as first line therapy in NSCLC. Cetuximab was given with an initial dose of $400 \mathrm{mg} / \mathrm{m}^{2}$ followed by weekly dose of $250 \mathrm{mg} / \mathrm{m}^{2}$. Cis/Vin: cisplatin/vinorelbin; CT: carboplatin/taxane (paclitaxel or docetaxel). PFS: progression free survival; OS: overall survival.

\begin{tabular}{|c|c|c|c|c|}
\hline Authors & Drugs & Patients & Response rate & Toxicity \\
\hline Phase III [85] & $\begin{array}{l}\text { Arm A: cetuximab }+ \text { Cis/Vin } \\
\text { Arm B: Cis/Vin alone }\end{array}$ & $\mathrm{n}=1125$ & $\begin{array}{r}\text { PFS: Arm A }=4.8 \text { months } \\
\text { Arm B }=4.8 \text { months } \\
\text { OS: Arm A }=10.1 \text { months } \\
\text { Arm B }=11.3 \text { months }\end{array}$ & $\begin{array}{l}\text { Grade } \geq 3 \text { rash: } \\
\text { Arm A: } 10 \% \\
\text { Arm B: }<1 \% \\
\text { Grade } \geq 3 \text { febrile neutropenia: } \\
\text { Arm A: } 22 \% \\
\text { Arm B: } 15 \%\end{array}$ \\
\hline Phase III [86] & $\begin{array}{l}\text { Arm A: cetuximab + CT } \\
\text { Arm B: CT alone }\end{array}$ & $n=676$ & $\begin{array}{r}\text { PFS: Arm A }=4.4 \text { months } \\
\text { Arm B }=4.24 \text { months } \\
\text { OS: Arm A }=9.69 \text { months } \\
\text { Arm B }=8.38 \text { months }\end{array}$ & $\begin{array}{c}\text { Grade } \geq 3 \text { rash: } \\
\text { Arm A: } 10.8 \% \\
\text { Arm B: } 0 \% \\
\text { Grade } \geq 3 \text { febrile neutropenia: } \\
\text { Arm A: } 4.6 \% \\
\text { Arm B: } 3.4 \%\end{array}$ \\
\hline
\end{tabular}


OS was enhanced by 1.2 and 1.3 months respectively with addition of cetuximab to chemotherapy $[85,86]$. However PFS reflected better than OS the efficacy of the first line therapy. OS is influenced by the treatment given after the first-line therapy and no data were provided about second line therapy in these studies. Based on these two trials, cetuximab was not approved by the EMEA or the FDA. EMEA considered that the drug had no convincing effect while the toxicity was considerable.

\subsection{Cetuximab: Future Directions}

\subsubsection{Cetuximab and Other Targeted Therapies}

Combining an anti-EGFR antibody and an EGFR TKI may enhance the inhibition of downstream signaling by blocking the different target sites on EGFR (extracellular and intracellular domains) [87]. Bortezomib which is the first drug of a new class of targeted drugs that are proteasome inhibitors may be also synergistic with cetuximab [88]. Despite the benefit in preclinical studies, association of cetuximab with TKI or bortezomid did not lead to objective response in phase II trials [88-93]. To the best of our knowledge, no phase III has yet started.

\subsubsection{Cetuximab and Radiotherapy}

The combination modality chemotherapy and radiotherapy conferred a small but significant survival advantage over radiotherapy alone in NSCLC [94]. Concomitant cetuximab and radiotherapy prolonged the survival of patients with locally advanced squamous cell carcinoma of the head and neck better than radiotherapy alone [95].

Combination of cetuximab and radiation resulted toxicity mainly in oesophagitis and pneumonitis as toxicity. Proportion of these adverse events was similar to those obtained with radiotherapy alone in previous clinical studies [96-102]. Only one trial compared directly cetuximab and chemoradiotherapy to chemoradiotherapy. A small but non significant benefit was observed for OS with association [102]. PFS was similar in both groups. A phase III trial is in progress to compare carpolatin/ paclitaxel followed by radiotherapy plus cetuximab and concurrent chemotherapy followed by radiotherapy in locally advanced NSCLC. Results may change clinical practice as it is actually done in head and neck cancer but are not expected before 2014 [97].

\subsubsection{Aerosolized Cetuximab}

Our group is investigating cetuximab delivery by airways in NSCLC. We previously showed that aerosolized cetuximab passed slowly and poorly in blood in mice [103]. It also significantly decreased tumor growth in an ectopic model of lung tumors. The benefit to deliver cetuximab compared to the systemic route is still under evaluation.

\subsubsection{Cetuximab and Predictive Markers}

As for bevacizumab, the main challenge is to discover predictive markers of the response to cetuximab in NSCLC. In colorectal cancer, it was shown that cetuximab was only active on wild type KRAS cancer [104]. The two large phase III clinical trials (BMS099 and FLEX) showed that EGFR and K-Ras mutations were not correlated with cetuximab response in lung cancer $[86,105]$. However a post-hoc analysis of the FLEX study collecting and quantifying the immunohistochemical EGFR activity in tumors found that EGFR expression in tumor may be a predictive marker [106]. In another post-hoc analysis of the FLEX study, skin rash at first cycle was associated with better PFS and OS in patients treated with cetuximab [107]. Identification of predictive markers is a crucial challenge and results of post-hoc analysis should be confirmed in a prospective study.

\subsection{Other Anti-EGFR Antibodies}

Several other anti-EGFR mAb were tested or are currently under evaluation in NSCLC. Matuzumab, an IgG1 $m A b$, binds EGFR with an affinity a little lower than that of cetuximab but, matuzumab has a longer half-life ( $6-8$ days) $[108,109]$. Overall response rate of matuzumab combined with paclitaxel, as first line therapy, was $22 \%$. EGFR expression and the KRAS mutation status seemed to predict a clinical response to matuzumab [110]. Pemetrexed/matuzumab as second line therapy seemed to be superior to chemotherapy alone (objective response $11 \%$ vs $5 \%$ ) but difference was not statistically significant probably due to low patient inclusion $(\mathrm{n}=148)$ [111].

Nimotuzumab was engineered to reduce human immunogenicity and slow clearance from the body [112]. In two clinical trials, nimotuzumab administered weekly was well tolerated with no notable skin toxicity [113, 114]. Objective response rate ranged from $47 \%$ to $66 \%$ $[113,114]$. Other clinical trials are in progress. The combination of gefitinib/nimotuzumab is being compared to gefitinib alone in NSCLC patients and results are due soon [115]. Another study is comparing the combination of nimotuzumab/liposomal paclitaxel/carboplatin to chemotherapy alone in NSCLC patients [116]. The results of this trial are expected in 2014.

Panitumumab, a fully humanized $\operatorname{IgG} 2$ directed against EGFR, was assessed in a phase I escalating dose clinical trial but the maximum tolerated dose was not reached $[117,118]$. Panitumumab in association with motesanib, a small-molecule antagonist of vascular endothelial growth factor receptors 1,2 , and 3, platelet-derived growth factor receptor, and Kit was assessed recently in a clinical trial [119]. No response was observed in patients treated with panitumumab associated to motesanib. Various clinical trials testing panitumumab in NSCLC are currently 
in progress, one testing pre-operative chemoradiotherapy with or without panitumumab in advanced NSCLC patients [120] and two designed to evaluate the response rate to carboplatin/vinorelbin/panitumumab as first line therapy and the progression-free survival time for cisplatin/pemetrexed with or without panitumumab [121, 122].

Finally, necitumumab, a fully human IgG1 targeting the extracellular domain III of EGFR delivered alone did not show any therapeutic effect in NSCLC patients [123]. Necitumumab is being evaluated combined with cisplatin and gemcitabine in a phase III trial of advanced NSCLC [124]. Another phase III study comparing pemetrexed/ cisplatin/necitumumab to chemotherapy alone in chemonaive NSCLC was stopped prematurely [125]. According to the press release from the company, the independent Data Monitoring Committee (DMC) decided that new or recently enrolled patients should stop treatment because of safety concerns related to thromboembolisms (blood clots) in the experimental arm of the study [126].

\subsection{Anti-HER2 mAb}

Trastuzumab is a humanized monoclonal antibody IgG1 directed against Her2 receptor [127]. While, trastuzumab seemed to have greater antitumor activity against NSCLC xenografts than against breast cancer xenografts, clinical results in NSCLC are less encouraging probably due to heterogeneity of HER2 overproduction and technical difficulties to quantify HER2 expression in lung tissues [128-133]. Overall clinical trials showed that trastuzumab was well tolerated but efficacy was low whether it was given alone or combined with chemotherapy.

Pertuzumab is a mAb with a particular mechanism of action. It inhibits HER2 dimerization [134,135]. A phase I clinical trial in which 43 NSCLC chemonaïve patients were treated with pertuzumab i.v. every 3 weeks found 9.3\% grade $\geq 3$ adverse events and no response [136]. Lastly, a phase II clinical trial assesses the response to F-18-fluorodeoxyglucose positron emission tomography of the combination of erlotinib and pertuzumab and results are pending [137].

\section{Immune Modulating Antibodies}

In human cancer, somatic gene mutations and epigenetically dysregulated genes lead to products which are potentially recognized as nonself-antigens [138]. Failure of the immune system to recognize these foreign antigens and eradicate tumor cells is probably a key mechanism in tumor development and recurrence [139]. Local immune suppression, induction of tolerance, and systemic dysfunction in T-cell signaling are described as mechanism implicated in immune system failure [140,141]. Several immunomodulatory molecules have been targeted to treat
NSCLC. CTLA-4 is an immunoglobulin which is present on the surface of T cells. It binds to CD80 and CD86 on antigen-presenting cells [141]. Blocking the CTLA-4mediated termination signal with antibodies should prolong anti-tumor immune responses, resulting in enhanced tumor suppression. Programmed death-1 (PD-1) is a key immune receptor expressed by activated T cells [142]. Ligation of PD-1 by B7-H1 (PD-L1), expressed on tumor cells, inhibits proliferation and cytokine production by activated $\mathrm{T}$ cells and prevents immune response against tumor cells. In NSCLC, PD-L1 does not seem to be correlated with survival [143].

\subsection{Anti CTLA-4 Antibody}

Ipilimumab, an antibody targeting CTLA-4, was combined to carboplatin/paclitaxel as sequencial treatment (given after chemotherapy) or concurrent treatment or placebo in chemonaive NSCLC patients [144]. The overall incidence of treatment related grade $\geq 3$ adverse events was similar across arms. Sequential ipilimumab statistically improved PFS but not concurrent imipilmumab (4.1 vs 5.1 months). Immune related adverse events such as colitis, hypohysitis, hypopituitarism ranged from $15 \%$ to $20 \%$ with ipilimumab arm but $6 \%$ in control arm. A phase III trial comparing carboplatin/paclitaxel/ipilimumab to carboplatin/paclitaxel alone has just started [145]. The primary end point is overall survival. Tremelimumab (CP-675,206), an IgG2 specifically directed against CTLA-4 was recently assessed in a phase 2 clinical trial but results have not yet been published [146].

\subsection{Anti-Programmed Death 1 Antibody}

Safety of anti-PD-1 antibody in NSCLC was evaluated in two phase I clinical trials $[147,148]$. Overall, grade $\geq 3$ immunological reaction was low. Autoimmunity adverse events were uncommon comparatively with ipilimumab (anti-CTLA-4 antibody). Objective response was promising and ranged from $17 \%$ to $18 \%$ in pretreated NSCLC patients. None of PD-L1 negative tumors had objective response $[147,148]$. One phase I clinical trial assessed safety of anti-PD-L1 antibody in NSCLC [149]. Overall, only $9 \%$ of patients developed grade $\geq 3$ adverse events. Objective response occurred in $10 \%$ in pretreated patients [149].

\section{Antibodies against the Insulin Growth Factor (IGF) Pathway}

The IGF system comprises circulating ligands (IGF-1, IGF-2 and insulin) and cell-membrane receptors (IGF1R and IGF2R) [150]. IGF-1 is associated with higher risk of lung cancer [151]. IGF1R is overexpressed in NSCLC and implicated in resistance to therapy [152]. Moreover, 
the presence of IGF1-R is associated with shorter disease-free survival times in NSCLC patients and is a potential target for NSCLC treatment [153].

Figitumumab (CP-751,871), an IgG2 antibody specific for IGF1-R was combined with paclitaxel/carboplatin or docetaxel in two clinical trials [154-156]. Compared to chemotherapy alone, figitumumab + paclitaxel/carboplatin led to more hyperglycemia $(8 \%$ and $15 \%$ respectively). Objective response rate with the combination was $54 \%$ and $42 \%$ with chemotherapy alone. Baseline free IGF-1 concentration was correlated with the clinical benefit of figitumumab [157]. A phase III study in which NSCLC patients were given carboplatin/paclitaxel/figitumumab or chemotherapy alone was shut down early because of too many deaths linked to figitumumab therapy [158]. The results of the study indicated that the overall survival of patients given figitumumab plus chemotherapy (8.5 months) was worse than for those given chemotherapy alone (10.3 months) [159]. However, figitumumab/chemotherapy was associated with better overall survival than was chemotherapy alone in a subset of patients with high baseline circulating IGF1-R. A phase III trial that compared erlotinib/figitumumab and erlotinib alone as a second-line therapy for NSCLC patients was prematurely closed because there was no improvement in the progression-free survival time in intermediate analyses [160]. Dalotuzumab (MK-0646 or $\mathrm{h} 7 \mathrm{C} 10$ ), directed against IGF-1R, was administered in 80 patients with various cancers and the treatment was well tolerated [161]. Another phase I/IIa trial assessed the safety of erlotinib/dalotuzumab in previously treated NSCLC patients [162]. Results are expected soon. The response to dalotuzumab combined with pemetrexed/cisplatin or gemcitabine/carboplatin is currently assessed $[163,164]$. Cixitumumab (IMC-A12), RG1507, Ganitumab, fully human IgG1 and BIIB022, a fully human IgG4 are currently evaluated in NSCLC combined with chemotherapy or targeted therapies [165-172].

\section{TRAIL Agonist Antibodies}

The tumour necrosis factor-related apoptosis-inducing ligand (TRAIL), also known as Apo2L, is a member of the TNF ligand superfamily $[173,174]$. It induces apoptosis in many cancer cell lines, with little or no effect on most normal cells [173]. TRAIL mediates apoptosis through two death receptors, TRAIL-receptor 1 (TRAILR1) and TRAIL-receptor 2 (TRAIL-R2) expressed on cell surface. NSCLC patients have high tumor concentrations of TRAIL-R1 (in $67 \%$ to $99 \%$ of tumor biopsies) $[175,176]$. TRAIL-R2 was detected in $82 \%$ of NSCLC tumor biopsies [176]. Several antibodies which are TRAIL agonist have been developed [177].

In two NSCLC clinical trials, Mapatumumab, an ago- nist antibody of TRAIL R1 receptor, was well tolerated $[178,179]$. The most common grade $\geq 3$ adverse event was back pain. Administered alone, no objective response was shown and combined with chemotherapy, it did not improve response rate or PFS in comparison of chemotherapy alone $[178,179]$. To the best of our knowledge, no phase III trial has yet been organized. Lexatumumab (HGS-ETR2), an agonistic high-affinity antibody that activates TRAIL-R2 (or death receptor 5), was assessed in 8 NSCLC patients among 31 cancer patients [180]. One patient given $10 \mathrm{mg} / \mathrm{kg}$ experienced a possibly dose-related toxicity of grade 3 hyperamylasemia. The outcome of the NSCLC patients was not given. Conatumumab (AMG 655), an agonistic antibody TRAILR2, did not lead to dose-limiting toxicities [181]. Only one patient with NSCLC had a confirmed partial response at week 32 (38\% reduction in tumor size) [181]. This patient remains on conatumumab after 4.2 years with a sustained partial response [181]. Tigatuzumab (TRA-8), another agonist of TRAIL-R2 was well tolerated in 17 cancer patients, but no NSCLC patient was included [182]. The maximum tolerated dose was not reached. No clinical trial on lung cancer patients is planned.

\section{Anti-IL-6 Antibody: ALD518}

Inflammation is associated with $15 \%-20 \%$ of all deaths from cancer worldwide and contributes to fragility of cancer patients [183]. IL-6 is an inflammatory cytokine which play an important role in NSCLC [184]. Elevated plasma IL-6 concentrations were associated with a poor prognosis in NSCLC [185]. ALD518 is a humanized IgG1 monoclonal antibody that binds with high affinity to human IL-6. The 124 NSCLC patients in a phase II study were given increasing doses of ALD518 [186,187]. The hemoglobin concentration was higher in the patients given ALD518 than in the placebo group. Moreover, the pooled subjects treated with ALD518 lost statistically less of lean body mass (LBM).

\section{Anti-NeuGcGM3: Racotumomab}

Neu-glycolyl-containing gangliosides (NeuGcGM3) are glycolipids that are not normally components of the cytoplasmic membranes of humans. But Neu-glycolylcontaining gangliosides are overproduced by several human tumors [188]. Racotumomab is an anti-idiotype murine monoclonal antibody which reacts with NeuGc-containing gangliosides. A group of 71 previously treated NSCLC patients were given racotumomab in a phase II trial with no serious adverse effects [189]. The median survival time of the 56 patients who entered the study with a partial response or a stable disease and with a PS 1 after the first line of chemo/radiotherapy was 11.50 
months from starting treatment. In contrast, the median survival time calculated for patients who started treatment with progressive disease and/or a PS2 was 6.50 months.

\section{Perspectives}

To enhance antibody properties, several molecules have been conjugated to the antibodies. As discussed in the first part, conjugation of mAbs with radionuclides may enhance their anti-tumor efficacy. Several radiolabeled antibodies are being evaluated for treating NSCLC. Two clinical trials showed that the toxicity of radiolabeled monoclonal antibody mCC49 directed against tumorassociated glycoprotein-72 (TAG-72) was acceptable, but the conjugate compound was no better than the unconjugated $\mathrm{mAb}[190,191]$. The radiolabeled cT84.66 monoclonal antibody directed against CEA (Carcinoembryonic antigen) will be assessed soon in patients with stage IIB, stage IIIA, or stage IIIB non-small cell lung cancer [192]. Conjugation of mAbs with cytotxic drugs were assessed in two phase II clinical studies on NSCLC patients. The first obtained some good results by giving SGN-15 (cBR96-doxorubicin conjugate) consisting of a chimeric murine monoclonal antibody that recognizes the Lewis Y antigen, conjugated to doxorubicin, in NSCLC patients [193]. In the second trial, ABR-217620 (naptumomab estafenatox), a recombinant fusion protein consisting of a mutated variant of the superantigen staphylococcal enterotoxin E (SEA/E-120) linked to a Fab fragment that recognizes the tumor-associated antigen 5T4, was given alone or in combination with docetaxel [194]. The treatment was well tolerated with evidence of immunological and antitumor activity.

Table 5. Status of therapeutic antibodies in NSCLC.

\begin{tabular}{|c|c|c|c|c|}
\hline & Target & Type & Immunoglobulin sub-class & Status in NSCLC \\
\hline Bevacizumab & VEGF & Humanized & IgG1 & Approved \\
\hline Ramucirumab & VEGFR-2 & Fully human & IgG1 & Phase III \\
\hline Cetuximab & EGFR & Chimeric & IgG1 & Phase III (Refusal) \\
\hline Matuzumab & EGFR & Humanized & IgG1 & Phase II \\
\hline Nimotuzumab & EGFR & Humanized & IgG1 & Phase II \\
\hline Panitumumab & EGFR & Fully Human & IgG2 & Phase II \\
\hline Necitumumab & EGFR & Fully Human & IgG1 & Phase III \\
\hline Trastuzumab & HER2 & Humanized & IgG1 & Phase II \\
\hline Pertuzumab & HER dimerization & Humanized & IgG1 & Phase II \\
\hline Figitumumab & IGF1-R & Fully human & $\operatorname{IgG} 2$ & Phase III \\
\hline Dalotuzumab & IGF1-R & Humanized & IgG1 & Phase II \\
\hline Cixitumumab & IGF1-R & Fully human & IgG1 & Phase II \\
\hline BIIB022 & IGF1-R & Fully human & IgG4P & Phase I \\
\hline RG1507 & IGF1-R & Fully human & IgG1 & Phase II \\
\hline Ipilimumab & CTLA-4 & Fully human & IgG1 & Phase III \\
\hline Tremelimumab & CTLA-4 & Fully human & $\operatorname{IgG} 2$ & Phase II \\
\hline Anti-PD-1 & PD-1 & Fully human & IgG4 & Phase I \\
\hline Anti-PD-L1 & PD-L1 & Fully human & IgG4 & Phase I \\
\hline ALD518 & IL-6 & Humanized & IgG1 & Phase II \\
\hline Mapatumumab & TRAIL-R1 (agonist) & Fully human & IgG1 & Phase II \\
\hline Lexatumumab & TRAIL-R2 (agonist) & Fully human & $\operatorname{IgG1}$ & Phase I \\
\hline Conatumumab & TRAIL-R2 (agonist) & Fully human & $\operatorname{IgG1}$ & Phase I \\
\hline Tigatuzumab & TRAIL-R2 (agonist) & Humanized & IgG1 & Phase I \\
\hline Racotumomab & NeuGcGM3 & Murin & $\mathrm{Ab} 2$ & Phase II \\
\hline Bavituximab & Phosphatidylserine & Chimeric & IgG1 & Phase II \\
\hline
\end{tabular}




\section{Conclusion}

NSCLC is a cancer with a particularly poor prognosis that is generally refractory to anti-cancer treatments. Monoclonal antibodies offer new promising ways of treating NSCLC (Table 5). Only one antibody, bevacizumab, is presently approved for NSCLC, but the progression-free survival time is short. Another mAb, cetuximab, was evaluated in several clinical trials and showed a small increase of overall survival in combination with chemotherapy. However, the FDA and the EMEA considered the therapeutic benefit insufficient and refused to approve cetuximab for treating NSCLC. At first glance, the results for NSCLC are somewhat disappointing, in contrast to the benefits obtained with mAb treatments in other solid tumors, such as breast and colon cancers. However, we believe this is only the visible part of the iceberg. The first steps towards treating NSCLC with therapeutic mAbs have been taken. Research and development of mAbs and derived compounds are a great challenge for both industry and academic institutions and countless possibilities remain to be explored. As proof, many $\mathrm{mAb}$ that have been approved for other cancers and new $\mathrm{mAbs}$ are being clinically evaluated for use with NSCLC. Cetuximab and anti-EGFR mAbs have not yet been abandoned as NSCLC treatments. Indeed, cetuximab is currently being tested in combination with radiation in clinical trials. New anti-cancer targets are being discovered every year and $\mathrm{mAb}$ technology to engineer more efficient biologics continues to evolve. Thus, the development of monoclonal antibodies clearly marks the start of a new era in NSCLC treatment, although there is still a long way to go before those "magic bullets" find their optimal target in lung cancer.

\section{Acknowledgements}

This publication was funded by the French National Research Agency under the program "Investissements d'avenir" Grant Agreement LabEx MAbImprove: ANR10-LABX-53. It was also supported by the "fond de dotation en santé respiratoire", "Cancéropôle Grand Ouest", "Région Centre" and "Association régionale d'aide aux insuffisants respiratoires".

The English text was edited by Dr Owen Parkes.

\section{REFERENCES}

[1] R. Govindan, N. Page, D. Morgensztern, W. Read, R. Tierney, A. Vlahiotis, E. L. Spitznagel and J. Piccirillo, "Changing Epidemiology of Small-Cell Lung Cancer in the United States over the Last 30 Years: Analysis of the Surveillance, Epidemiologic, and End Results Database," J. Clin. Oncol., Vol. 24, No. 28, 2006, pp. 4539-4544. doi:10.1200/JCO.2005.04.4859

[2] C. G. Azzoli, S. Temin, T. Aliff, S. Baker Jr., J. Brahmer,
D. H. Johnson, J. L. Laskin, G. Masters, D. Milton, L. Nordquist, W. Pao, D. G. Pfister, S. Piantadosi, J. H. Schiller, R. Smith, T. J. Smith, J. R. Strawn, D. Trent and G. Giaccone, "2011 Focused Update of 2009 American Soci y of Clinical Oncology Clinical Practice Guideline Update on Chemotherapy for Stage IV Non-Small-Cell Lung Cancer," Journal of Clinical Oncology, Vol. 29, No. 28, 2011, pp. 3825-3831. doi:10.1200/JCO.2010.34.2774

[3] S. G. Spiro, R. M. Rudd, R. L. Souhami, J. Brown, D. J. Fairlamb, N. H. Gower, L. Maslove, R. Milroy, V. Napp, M. K. B. Parmar, M. D. Peake, R. J. Stephens, H. Thorpe, D. A. Waller and P. West, "Chemotherapy versus Supportive Care in Advanced Non-Small Cell Lung Cancer: Improved Survival without d Riment to Quality of Life," Thorax, Vol. 59, No. 10, 2004, pp. 828-836.

doi:10.1136/thx.2003.020164

[4] D. J. Slamon, B. Leyland-Jones, S. Shak, H. Fuchs, V. Paton, A. Bajamonde, T. Fleming, W. Eiermann, J. Wolter, M. Pegram, J. Baselga and L. Norton, "Use of Chemotherapy plus a moNoclonal Antibody against HER2 for $m$ Astatic Breast Cancer That Overexpresses HER2," New England Journal of Medicine, Vol. 344, No. 11, 2001, pp. 783-792. doi:10.1056/NEJM200103153441101

[5] H. Hurwitz, L. Fehrenbacher, W. Novotny, T. Cartwright, J. Hainsworth, W. Heim, J. Berlin, A. Baron, S. Griffing, E. Holmgren, N. Ferrara, G. Fyfe, B. Rogers, R. Ross and F. Kabbinavar, "Bevacizumab plus iriNotecan, Fluorouracil, and Leucovorin for m Astatic Colorectal Cancer," New England Journal of Medicine, Vol. 350, No. 23, 2004, pp. 2335-2342. doi:10.1056/NEJMoa032691

[6] G. W. Litman, J. P. Rast, M. J. Shamblott, R. N. Haire, M. Hulst, W. Roess, R. T. Litman, K. R. Hinds-Frey, A. Zilch and C. T. Amemiya, "Phylogenetic Diversification of Immunoglobulin Genes and the Antibody Repertoire," Molecular Biology and Evolution, Vol. 10, No. 1, 1993, pp. 60-72.

[7] F. Winau, O. Westphal and R. Winau, "Paul Ehrlich-In Search of the Magic Bullet," Microbes and Infection, Vol. 6, No. 8, 2004, pp. 786-789. doi:10.1016/j.micinf.2004.04.003

[8] G. Köhler and C. Milstein, "Continuous Cultures of Fused Cells Secring Antibody of Predefined Specificity," Nature, Vol. 256, No. 5517, 1975, pp. 495-497. doi: $10.1038 / 256495 \mathrm{a} 0$

[9] D. L. Shawler, R. M. Bartholomew, L. M. Smith and R. O. Dillman, "Human Immune Response to Multiple Injections of Murine moNoclonal IgG," Journal of Immunology, Vol. 135, No. 2, 1985, pp. 1530-1535.

[10] D. R. Getts, M. T. Getts, D. P. McCarthy, E. M. L. Chastain and S. D. Miller, "Have We Overestimated the Benefit of Human(ized) Antibodies?" MAbs, Vol. 2, No. 6, 2010, pp. 682-694. doi:10.4161/mabs.2.6.13601

[11] G. L. Boulianne, N. Hozumi and M. J. Shulman, "Production of Functional Chimaeric Mouse/Human Antibody," Nature, Vol. 312, No. 5995, 1984, pp. 643-646. doi: $10.1038 / 312643 \mathrm{a} 0$

[12] P. T. Jones, P. H. Dear, J. Foote, M. S. Neuberger and G. Winter, "Replacing the Complementarity-Determining 
Regions in a Human Antibody with Those from a Mouse," Nature, Vol. 321, No. 6069, 1986, pp. 522-525. doi: $10.1038 / 321522 \mathrm{a} 0$

[13] S. J. Kim, Y. Park and H. J. Hong, "Antibody Engineering for the Development of Therapeutic Antibodies," Molecules and Cells, Vol. 20, No. 1, 2005, pp. 17-29.

[14] W. Y. K. Hwang and J. Foote, "ImmuNogenicity of Engineered Antibodies," Methods, Vol. 36, No. 1, 2005, pp. 3-10. doi:10.1016/j.ymeth.2005.01.001

[15] E. Kaneko and R. Niwa, "Optimizing Therapeutic Antibody Function: Progress with Fc Domain Engineering," BioDrugs, Vol. 25, No. 1, 2011, pp. 1-11. doi:10.2165/11537830-000000000-00000

[16] K. A. Gelderman, S. Tomlinson, G. D. Ross and A. Gorter, "Complement Function in mAb-Mediated Cancer ImmuNotherapy," Trends in Immunology, Vol. 25, No. 3, 2004, pp. 158-164. doi:10.1016/j.it.2004.01.008

[17] M. Watanabe, P. K. Wallace, T. Keler, Y. M. Deo, C. Akewanlop and D. F. Hayes, "Antibody Dependent Cellular Phagocytosis (ADCP) and Antibody Dependent Cellular Cytotoxicity (ADCC) of Breast Cancer Cells Mediated by Bispecific Antibody, MDX-210," Breast Cancer Research and Treatment, Vol. 53, No. 3, 1999, pp. 199-207. doi:10.1023/A:1006145507567

[18] D. M. Goldenberg, "Targeted Therapy of Cancer with Radiolabeled Antibodies," Journal of Nuclear Medicine, Vol. 43, No. 5, 2002, pp. 693-713.

[19] F. R. Brennan, L. D. Morton, S. Spindeldreher, A. Kiessling, R. Allenspach, A. Hey, P. Y. Muller, W. Frings and J. Sims, "Safety and Immunotoxicity Assessment of Immunomodulatory Monoclonal Antibodies," MAbs, Vol. 2, No. 3, 2010, pp. 233-255. doi:10.4161/mabs.2.3.11782

[20] T. T. Hansel, H. Kropshofer, T. Singer, J. A. Mitchell and A. J. T. George, "The Safety and Side Effects of Monoclonal Antibodies," Nature Reviews Drug Discovery, Vol. 9, No. 4, 2010, pp. 325-338. doi:10.1038/nrd3003

[21] P. J. Bugelski, R. Achuthanandam, R. J. Capocasale, G. Treacy and E. Bouman-Thio, "MoNoclonal AntibodyInduced Cytokine-Release Syndrome," Expert Review of Clinical Immunology, Vol. 5, No. 5, 2009, pp. 499-521. doi:10.1586/eci.09.31

[22] R. J. Keizer, A. D. R. Huitema, J. H. M. Schellens and J. H. Beijnen, "Clinical Pharmacokin Ics of Therapeutic Monoclonal Antibodies," Clinical Pharmacokinetics, Vol. 49, No. 8, 2010, pp. 493-507. doi:10.2165/11531280-000000000-00000

[23] T. T. Kuo, K. Baker, M. Yoshida, S.-W. Qiao, V. G. Aveson, W. I. Lencer and R. S. Blumberg, "Neonatal Fc Receptor: From Immunity to Therapeutics," Journal of Clinical Immunology, Vol. 30, No. 6, 2010, pp. 777-789. doi:10.1007/s10875-010-9468-4

[24] L. H. Stockwin and S. Holmes, "Antibodies as Therapeutic Agents: Vive la Renaissance!" Expert Opinion on Biological Therapy, Vol. 3, No. 7, 2003, pp. 1133-1152. doi:10.1517/14712598.3.7.1133

[25] J. M. Reichert, "Which Are the Antibodies to Watch in 2012?" MAbs, Vol. 4, No. 1, 2012, pp. 1-3. doi:10.4161/mabs.4.1.18719

[26] N. Ferrara, H.-P. Gerber and J. LeCouter, "The Biology of VEGF and Its Receptors," Nature Medicine, Vol. 9, No. 6, 2003, pp. 669-676. doi:10.1038/nm0603-669

[27] G. Fontanini, L. Boldrini, S. Chinè, F. Pisaturo, F. Basolo, A. Calcinai, M. Lucchi, A. Mussi, C. A. Angeletti and G. Bevilacqua, "Expression of Vascular Endothelial Growth Factor mRNA in Non-Small-Cell Lung Carcinomas," British Journal of Cancer, Vol. 79, No. 2, 1999, pp. 363369. doi:10.1038/sj.bjc. 6690058

[28] K. Kadota, C.-L. Huang, D. Liu, M. UeNo, Y. Kushida, R. Haba and H. Yokomise, "The Clinical Significance of Lymphangiogenesis and Angiogenesis in Non-Small Cell Lung Cancer Patients," European Journal of Cancer, Vol. 44, No. 7, 2008, pp. 1057-1067. doi:10.1016/j.ejca.2008.03.012

[29] P. Zhan, J. Wang, X. Lv, Q. Wang, L. Qiu, X. Lin, L. Yu and Y. Song, "Prognostic Value of Vascular Endothelial Growth Factor Expression in Patients with Lung Cancer: A Systematic Review with Meta-Analysis," Journal of Thoracic Oncology, Vol. 4, No. 9, 2009, pp. 1094-1103. doi:10.1097/JTO.0b013e3181a97e31

[30] L. G. Presta, H. Chen, S. J. O’ConNor, V. Chisholm, Y. G. Meng, L. Krummen, M. Winkler and N. Ferrara, "Humanization of an Anti-Vascular Endothelial Growth Factor Monoclonal Antibody for the Therapy of Solid Tumors and Other Disorders," Cancer Research, Vol. 57, No. 20, 1997, pp. 4593-4599.

[31] D. H. Johnson, L. Fehrenbacher, W. F. Novotny, R. S. Herbst, J. J. Nemunaitis, D. M. Jablons, C. J. Langer, R. F. DeVore III, J. Gaudreault, L. A. Damico, E. Holmgren and F. Kabbinavar, "Randomized Phase II Trial Comparing Bevacizumab plus Carboplatin and Paclitaxel with Carboplatin and Paclitaxel Alone in Previously Untreated Locally Advanced or Metastatic Non-Small-Cell Lung Cancer," Journal of Clinical Oncology, Vol. 22, No. 11, 2004, pp. 2184-2191. doi:10.1200/JCO.2004.11.022

[32] J. D. Hainsworth, L. Fang, J. E. Huang, D. Karlin, K. Russell, L. Faoro and C. Azzoli, "BRIDGE: An OpenLabel Phase II Trial Evaluating the Safety of Bevacizumab + Carboplatin/Paclitaxel as First-Line Treatment for Patients with Advanced, Previously Untreated, Squamous Non-Small Cell Lung Cancer," Journal of Thoracic Oncology, Vol. 6, No. 1, 2011, pp. 109-114.

doi:10.1097/JTO.0b013e3181f94ad4

[33] R. S. Heist, P. Fidias, M. Huberman, B. Ardman, L. V. Sequist, J. S. Temel and T. J. Lynch, "A Phase II Study of Oxaliplatin, Pemetrexed, and Bevacizumab in Previously Treated Advanced Non-Small Cell Lung Cancer," Journal of Thoracic Oncology, Vol. 3, No. 10, 2008, pp. 1153 1158. doi:10.1097/JTO.0b013e318187273f

[34] P. Correale, C. Remondo, S. F. Carbone, V. Ricci, C. Migali, I. Martellucci, A. Licchetta, R. Addeo, L. Volterrani, G. Gotti, M. S. Rotundo, P. Tassone, P. Sperlongano, A. Abbruzzese, M. Caraglia, P. Tagliaferri and G. Francini, "Dose/Dense Metronomic Chemotherapy with Fractioned Cisplatin and Oral Daily Etoposide Enhances the Anti-Angiogenic Effects of Bevacizumab and Has Strong Antitumor Activity in Advanced Non-Small-Cell-Lung 
Cancer Patients," Cancer Biology \& Therapy, Vol. 9, No. 9, 2010, pp. 685-693. doi:10.4161/cbt.9.9.11441

[35] W. N. William Jr., M. S. Kies, F. V. Fossella, D. D. Liu, G. Gladish, W. H. Tse, J. J. Lee, W. K. Hong, S. M. Lippman and E. S. Kim, "Phase 2 Study of Carboplatin, Docetaxel, and Bevacizumab as Frontline Treatment for Advanced Nonsmall-Cell Lung Cancer," Cancer, Vol. 116 , No. 10, 2010, pp. 2401-2408. doi:10.1097/JTO.0b013e3181f1d23c

[36] C. Clément-Duchêne, Y. Krupitskaya, K. Ganjoo, P. Lavori, A. McMillan, A. Kumar, G. Zhao, S. Padda, L. Zhou, M. S. Pedro-Salcedo, A. D. Colevas and H. A. Wakelee, "A Phase II First-Line Study of Gemcitabine, Carboplatin, and Bevacizumab in Advanced Stage Nonsquamous Non-Small Cell Lung Cancer," Journal of Thoracic Oncology, Vol. 5, No. 11, 2010, pp. 1821-1825.

[37] A. Sandler, R. Gray, M. C. Perry, J. Brahmer, J. H. Schiller, A. Dowlati, R. Lilenbaum and D. H. Johnson, "Paclitaxel-Carboplatin Alone or with Bevacizumab for Non-Small-Cell Lung Cancer," New England Journal of Medicine, Vol. 355, No. 24, 2006, pp. 2542-2550. doi:10.1056/NEJMoa061884

[38] M. Reck, J. von Pawel, P. Zatloukal, R. Ramlau, V. GorbouNova, V. Hirsh, N. Leighl, J. Mezger, V. Archer, N. Moore and C. Manegold, "Phase III Trial of Cisplatin plus Gemcitabine with either Placebo or Bevacizumab as First-Line Therapy for Nonsquamous Non-Small-Cell Lung Cancer: AVAil," Journal of Clinical Oncology, Vol. 27, No. 8, 2009, pp. 1227-1234. doi:10.1200/JCO.2007.14.5466

[39] L. Crinò, E. Dansin, P. Garrido, F. Griesinger, J. Laskin, N. Pavlakis, D. Stroiakovski, N. Thatcher, C.-M. Tsai, Y. $\mathrm{Wu}$ and $\mathrm{C}$. Zhou, "Safety and Efficacy of First-Line Bevacizumab-Based Therapy in Advanced Non-Squamous Non-Small-Cell Lung Cancer (SAiL, MO19390): A Phase 4 Study," Lancet Oncology, Vol. 11, No. 8, 2010, pp. 733-740. doi:10.1016/S1470-2045(10)70151-0

[40] S. S. Ramalingam, S. E. Dahlberg, C. J. Langer, R. Gray, C. P. Belani, J. R. Brahmer, A. B. Sandler, J. H. Schiller and D. H. Johnson, "Outcomes for Elderly, AdvancedStage Non Small-Cell Lung Cancer Patients Treated with Bevacizumab in Combination with Carboplatin and $\mathrm{Pa}-$ clitaxel: Analysis of Eastern Cooperative Oncology Group Trial 4599," Journal of Clinical Oncology, Vol. 26, No. 1, 2008, pp. 60-65. doi:10.1200/JCO.2007.13.1144

[41] N. B. Leighl, P. Zatloukal, J. Mezger, R. Ramlau, N. Moore, M. Reck and C. Manegold, "Efficacy and Safety of Bevacizumab-Based Therapy in Elderly Patients with Advanced or Recurrent Nonsquamous Non-Small Cell Lung Cancer in the Phase III BO17704 Study (AVAiL)," Journal of Thoracic Oncology, Vol. 5, No. 12, 2010, pp. 1970-1976. doi:10.1097/JTO.0b013e3181f49c22

[42] J. Laskin, L. Crinò, E. Felip, F. Franke, V. Gorbunova, H. Groen, G.-L. Jiang, M. Reck and C.-P. Schneider, "Safety and Efficacy of First-Line Bevacizumab plus Chemotherapy in Elderly Patients with Advanced or Recurrent Nonsquamous Non-Small Cell Lung Cancer: Safety of Avastin in Lung Trial (MO19390)," Journal of Thoracic Oncology, Vol. 7, No. 1, 2012, pp. 203-211. doi:10.1097/JTO.0b013e3182370e02
[43] J. Zhu, D. B. Sharma, S. W. Gray, A. B. Chen, J. C. Weeks and D. Schrag, "Carboplatin and Paclitaxel with vs without Bevacizumab in Older Patients with Advanced Non-Small Cell Lung Cancer," JAMA, Vol. 307, No. 15, 2012, pp. 1593-1601. doi:10.1001/jama.2012.454

[44] J. D. Patel, T. A. Hensing, A. Rademaker, E. M. Hart, M. G. Blum, D. T. Milton and P. D. Bonomi, "Phase II Study of Pemetrexed and Carboplatin plus Bevacizumab with Maintenance Pemetrexed and Bevacizumab as First-Line Therapy for Nonsquamous Non-Small-Cell Lung Cancer," Journal of Clinical Oncology, Vol. 27, No. 20, 2009, pp. 3284-3289. doi:10.1200/JCO.2008.20.8181

[45] J. D. Patel, P. BoNomi, M. A. Socinski, R. Govindan, S. Hong, C. Obasaju, E. J. Pennella, A. C. Girvan and S. C. Guba, "Treatment Rationale and Study Design for the Pointbreak Study: A Randomized, Open-Label Phase III Study of Pemetrexed/Carboplatin/Bevacizumab Followed by Maintenance Pemetrexed/Bevacizumab versus Paclitaxel/Carboplatin/Bevacizumab Followed by Maintenance Bevacizumab in Patients with Stage IIIB or IV Nonsquamous Non-Small-Cell Lung Cancer," Clinical Lung Cancer, Vol. 10, No. 4, 2009, pp. 252-256. doi:10.3816/CLC.2009.n.035

[46] D. Galetta, S. Pisconti, S. Cinieri, G. L. Pappagallo, V. Gebbia, N. BorselliNo, E. Maiello, A. Rinaldi, M. Montrone, P. Rizzo, N. MarzaNo, N. Sasso, A. Febbraro and G. Colucci, "Induction Pemetrexed and Cisplatin Followed by Maintenance Pemetrexed versus Carboplatin plus Paclitaxel plus Bevacizumab Followed by Maintenance Bevacizumab: A Quality of Life-Oriented Randomized Phase III Study in Patients with Advanced Non-Squamous Non-Small-Cell Lung Cancer (ERACLE)," Clinical Lung Cancer, Vol. 12, No. 6, 2011, pp. 402-406. doi:10.1016/j.cllc.2011.06.006

[47] R. G. Zinner, S. B. Saxman, G. Peng, M. J. Monberg and W. I. Ortuzar, "Treatment Rationale and Study Design for a Randomized Trial of Pemetrexed/Carboplatin Followed by Maintenance Pemetrexed versus Paclitaxel/Carboplatin/Bevacizumab Followed by Maintenance Bevacizumab in Patients with Advanced Non-Small-Cell Lung Cancer of Nonsquamous Histology," Clinical Lung Cancer, Vol. 11, No. 5, 2010, pp. 352-357. doi:10.3816/CLC.2010.n.045

[48] C. Bankhead, "AVAPERL Trial Tests NSCLC Maintenance Regimens," Clinical Oncology, Vol. 6, No. 12, 2011.

[49] F. A. Shepherd, J. R. Pereira, T. Ciuleanu, E. H. Tan, V. Hirsh, S. Thongprasert, D. Campos, S. Maoleekoonpiroj, M. Smylie, R. Martins, M. van Kooten, M. Dediu, B. Findlay, D. Tu, D. Johnston, A. Bezjak, G. Clark, P. Santabárbara and L. Seymour, "Erlotinib in Previously Treated Non-Small-Cell Lung Cancer," New England Journal of Medicine, Vol. 353, No. 2, 2005, pp. 123-132. doi:10.1056/NEJMoa050753

[50] R. S. Herbst, R. Ansari, F. Bustin, P. Flynn, L. Hart, G. A. Otterson, G. Vlahovic, C.-H. Soh, P. O'ConNor and J. Hainsworth, "Efficacy of Bevacizumab Plus Erlotinib versus Erlotinib Alone in Advanced Non-Small-Cell Lung Cancer after Failure of Standard First-Line Chemotherapy (BeTa): A Double-Blind, Placebo-Controlled, 
Phase 3 Trial," Lancet, Vol. 377, No. 9780, 2011, pp. 1846-1854. doi:10.1016/S0140-6736(11)60545-X

[51] R. S. Herbst, D. H. Johnson, E. Mininberg, D. P. Carbone, T. Henderson, E. S. Kim, G. Blumenschein Jr., J. J. Lee, D. D. Liu, M. T. Truong, W. K. Hong, H. Tran, A. Tsao, D. Xie, D. A. Ramies, R. Mass, S. Seshagiri, D. A. Eberhard, S. K. Kelley and A. Sandler, "Phase I/II Trial Evaluating the Anti-Vascular Endothelial Growth Factor moNoclonal Antibody Bevacizumab in Combination with the HER-1/Epidermal Growth Factor Receptor Tyrosine Kinase Inhibitor Erlotinib for Patients with Recurrent Non-Small-Cell Lung Cancer," Journal of Clinical Oncology, Vol. 23, No. 11, 2005, pp. 2544-2555. doi:10.1200/JCO.2005.02.477

[52] R. S. Herbst, V. J. O’Neill, L. Fehrenbacher, C. P. Belani, P. D. BoNomi, L. Hart, O. Melnyk, D. Ramies, M. Lin and A. Sandler, "Phase II Study of Efficacy and Safety of Bevacizumab in Combination with Chemotherapy or Erlotinib Compared with Chemotherapy Alone for Treatment of Recurrent or Refractory Non Small-Cell Lung Cancer," Journal of Clinical Oncology, Vol. 25, No. 30, 2007, pp. 4743-4750. doi:10.1200/JCO.2007.12.3026

[53] A.-M. C. Dingemans, A. J. de Langen, V. van den Boogaart, J. T. Marcus, W. H. Backes, H. T. G. M. Scholtens, H. van Tinteren, O. S. Hoekstra, J. Pruim, B. Brans, F. B. Thunnissen, E. F. Smit and H. J. M. Groen, "First-Line Erlotinib and Bevacizumab in Patients with Locally Advanced and/or Metastatic Non-Small-Cell Lung Cancer: A Phase II Study Including Molecular Imaging," Annals of Oncology, Vol. 22, No. 3, 2011, pp. 559-566. doi:10.1093/annonc/mdq391

[54] V. A. Miller, P. O'ConNor, C. Soh and F. Kabbinavar, "A Randomized, Double-Blind, Placebo-Controlled, Phase IIIb Trial (ATLAS) Comparing Bevacizumab (B) Therapy with or without Erlotinib (E) after Completion of Chemotherapy with B for First-Line Treatment of Locally Advanced, Recurrent, or Metastatic Non-Small Cell Lung Cancer (NSCLC)," Journal of Clinical Oncology, Vol. 27, 2009 , p. 8002.

[55] A. M. Jubb, H. I. Hurwitz, W. Bai, E. B. Holmgren, P. Tobin, A. S. Guerrero, F. Kabbinavar, S. N. Holden, W. F. Novotny, G. D. Frantz, K. J. Hillan and H. Koeppen, "Impact of Vascular Endothelial Growth Factor-A Expression, Thrombospondin-2 Expression, and Microvessel Density on the Treatment Effect of Bevacizumab in Metastatic Colorectal Cancer," Journal of Clinical Oncology, Vol. 24, No. 2, 2006, pp. 217-227. doi:10.1200/JCO.2005.01.5388

[56] A. Dowlati, R. Gray, A. B. Sandler, J. H. Schiller and D. H. Johnson, "Cell Adhesion Molecules, Vascular Endothelial Growth Factor, and Basic Fibroblast Growth Factor in Patients with Non-Small Cell Lung Cancer Treated with Chemotherapy with or without Bevacizumab-An Eastern Cooperative Oncology Group Study," Clinical Cancer Research, Vol. 14, No. 5, 2008, pp. 1407-1412. doi:10.1158/1078-0432.CCR-07-1154

[57] S. E. Dahlberg, A. B. Sandler, J. R. Brahmer, J. H. Schiller and D. H. Johnson, "Clinical Course of Advanced Non-Small-Cell Lung Cancer Patients Experiencing Hypertension during Treatment with Bevacizumab in
Combination with Carboplatin and Paclitaxel on ECOG 4599," Journal of Clinical Oncology, Vol. 28, No. 6, 2010, pp. 949-954. doi:10.1200/JCO.2009.25.4482

[58] S. V. Kozin, Y. Boucher, D. J. Hicklin, P. Bohlen, R. K. Jain and H. D. Suit, "Vascular Endothelial Growth Factor Receptor-2-Blocking Antibody Potentiates Radiation-Induced Long-Term Control of Human Tumor Xenografts," Cancer Research, Vol. 61, No. 1, 2001, pp. 39-44.

[59] ImClone LLC, "A Study of Ramucirumab with Paclitaxel and Carboplatin in Non-Small Cell Lung Cancer," In: National Library of Medicine (US), ClinicalTrials.gov, Bethesda, 2000.

http://clinicaltrials.gov/show/NCT00735696NLMIdentifi er: NCT00735696

[60] ImClone LLC, "Eli Lilly and Company. A Study in Second Line Non Small Cell Lung Cancer," National Library of Medicine (US), ClinicalTrials.gov, Bethesda, 2000. http://clinicaltrials.gov/show/NCT01168973NLMIdentifi er: NCT01168973

[61] ImClone LLC, "A Study of Pemetrexed \& Carboplatin/Cisplatin or Gemcitabine \& Carboplatin/Cisplatin with or without imc-1121b in Patients Previously Untreated with Recurrent or Advanced Non-Small Cell Lung Cancer (NSCLC)," National Library of Medicine (US), ClinicalTrials.gov, Bethesda, 2000.

http:/clinicaltrials.gov/show/NCT01160744 NLM Identifier: NCT01160744

[62] D. L. Daleke, "Regulation of Transbilayer Plasma Membrane Phospholipid Asymmetry," Journal of Lipid Research, Vol. 44, No. 2, 2003, pp. 233-242. doi:10.1194/jlr.R200019-JLR200

[63] R. Digumarti, A. V. Suresh, G. S. Bhattacharyya, L. Dasappa, J. Shan; Nizams Institute of Medical Sciences, Hyderabad, India; Yashoda Hospital, Hyderabad, India; Orchid Nursing Home, Kolkata, India; Kidwai Institute of Oncology, Bangalore, India; Peregrine Pharmaceuticals, Inc. and C. A. Tustin, "Phase II Study of Bavituximab plus Paclitaxel and Carboplatin in Untreated Locally Advanced or Metastatic Non-Small Cell Lung Cancer: Interim Results," Journal of Clinical Oncology, Vol. 28, No 15s, 2010, Abstr 7589.

[64] Peregrine Pharmaceuticals, "Study of Paclitaxel/Carboplatin with or without Bavituximab in Previously Untreated Non Small-Cell Lung Cancer," National Library of Medicine (US), ClinicalTrials.gov, Bethesda, 2000. http://clinicaltrials.gov/show/NCT01160601NLMIdentifier NCT01160601

[65] Peregrine Pharmaceuticals, "Study of Bavituximab plus Docetaxel in Patients with Locally Advanced or Metastatic Non-Squamous Non Small-Cell Lung Cancer," National Library of Medicine (US), ClinicalTrials.gov, Bethesda, 2000.

http://clinicaltrials.gov/show/NCT01138163NLM Identifier NCT01138163

[66] N. E. Hynes and H. A. Lane, "ERBB Receptors and Cancer: The Complexity of Targeted Inhibitors," Nature Reviews Cancer, Vol. 5, No. 5, 2005, pp. 341-354. doi:10.1038/nrc1609

[67] V. Rusch, D. Klimstra, E. Venkatraman, P. W. Pisters, J. 
Langenfeld and E. Dmitrovsky, "Overexpression of the Epidermal Growth Factor Receptor and Its Ligand Transforming Growth Factor Alpha Is Frequent in Resectable Non-Small Cell Lung Cancer but Does Not Predict Tumor Progression," Clinical Cancer Research, Vol. 3, No. 4, 1997, pp. 515-522.

[68] G. Carpenter and S. Cohen, "Epidermal Growth Factor," Annual Review of Biochemistry, Vol. 48, 1979, pp. 193216. doi:10.1146/annurev.bi.48.070179.001205

[69] E. Tzahar, H. Waterman, X. Chen, G. Levkowitz, D. Karunagaran, S. Lavi, B. J. Ratzkin and Y. Yarden, "A Hierarchical Network of Interreceptor Interactions Determines Signal Transduction by Neu Differentiation Factor/Neuregulin and Epidermal Growth Factor," Molecular and Cellular Biology, Vol. 16, No. 10, 1996, pp. 52765287.

[70] M. Tateishi, T. Ishida, S. KohdoNo, M. Hamatake, Y. Fukuyama and K. Sugimachi, "Prognostic Influence of the Co-Expression of Epidermal Growth Factor Receptor and c-erbB-2 Protein in Human Lung Adenocarcinoma," Surgical Oncology, Vol. 3, No. 2, 1994, pp. 109-113. doi:10.1016/0960-7404(94)90006-X

[71] P. Heinmöller, C. Gross, K. Beyser, C. Schmidtgen, G. Maass, M. Pedrocchi and J. Rüschoff, "HER2 Status in Non-Small Cell Lung Cancer: Results from Patient Screening for Enrollment to a Phase II Study of Herceptin," Clinical Cancer Research, Vol. 9, No. 14, 2003, pp. 5238-5243.

[72] D. Tan, G. Deeb, J. Wang, H. K. Slocum, J. Winston, S. Wiseman, A. Beck, S. Sait, T. Anderson, C. Nwogu, N. Ramnath and G. Loewen, "HER-2/neu Protein Expression and Gene Alteration in Stage I-IIIA Non-Small-Cell Lung Cancer: A Study of 140 Cases Using a Combination of High Throughput Tissue Microarray, Immunohistochemistry, and Fluorescent in Situ Hybridization," Diagnostic Molecular Pathology, Vol. 12, No. 4, 2003, pp. 201-211. doi:10.1097/00019606-200312000-00004

[73] C. Pellegrini, M. Falleni, A. Marchetti, B. Cassani, M. Miozzo, F. Buttitta, M. Roncalli, G. Coggi and S. Bosari, "HER-2/Neu Alterations in Non-Small Cell Lung Cancer: A Comprehensive Evaluation by Real Time Reverse Transcription-PCR, Fluorescence in Situ Hybridization, and immuNohistochemistry," Clinical Cancer Research, Vol. 9, No. 10, 2003, pp. 3645-3652.

[74] F. Cappuzzo, M. Varella-Garcia, H. Shigematsu, I. Domenichini, S. Bartolini, G. L. Ceresoli, E. Rossi, V. Ludovini, V. Gregorc, L. Toschi, W. A. Franklin, L. Crino, A. F. Gazdar, P. A. Bunn Jr. and F. R. Hirsch, "Increased HER2 Gene Copy Number Is Associated with Response to Gefitinib Therapy in Epidermal Growth Factor Receptor-Positive Non-Small-Cell Lung Cancer Patients," Journal of Clinical Oncology, Vol. 23, No. 22, 2005, pp. 5007-5018. doi:10.1200/JCO.2005.09.111

[75] R. S. Herbst and D. M. Shin, "Monoclonal Antibodies to Target Epidermal Growth Factor Receptor-Positive Tumors: A New Paradigm for Cancer Therapy," Cancer, Vol. 94, No. 5, 2002, pp. 1593-1611. doi:10.1002/cncr.10372

[76] J. Baselga, D. Pfister, M. R. Cooper, R. Cohen, B. Burt- ness, M. Bos, G. D’Andrea, A. Seidman, L. Norton, K. Gunnett, J. Falcey, V. Anderson, H. Waksal and J. Mendelsohn, "Phase I Studies of Anti-Epidermal Growth Factor Receptor Chimeric Antibody C225 Alone and in Combination with Cisplatin," Journal of Clinical Oncology, Vol. 18, No. 4, 2000, pp. 904-914.

[77] C. D. Thienelt, P. A. Bunn Jr., N. Hanna, A. Rosenberg, M. N. Needle, M. E. Long, D. L. Gustafson and K. Kelly, "Multicenter Phase I/II Study of Cetuximab with Paclitaxel and Carboplatin in Untreated Patients with Stage IV Non-Small-Cell Lung Cancer," Journal of Clinical Oncology, Vol. 23, No. 34, 2005, pp. 8786-8793. doi:10.1200/JCO.2005.03.1997

[78] C. A. Butts, D. Bodkin, E. L. Middleman, C. W. Englund, D. Ellison, Y. Alam, H. Kreisman, P. Graze, J. Maher, H. J. Ross, P. M. Ellis, W. McNulty, E. Kaplan, V. Pautret, M. R. Weber and F. A. Shepherd, "Randomized Phase II Study of Gemcitabine plus Cisplatin or Carboplatin [Corrected], with or without Cetuximab, as First-Line Therapy for Patients with Advanced or Metastatic Non Small-Cell Lung Cancer," Journal of Clinical Oncology, Vol. 25, No. 36, 2007, pp. 5777-5784. doi:10.1200/JCO.2007.13.0856

[79] H. Borghaei, C. J. Langer, M. Millenson, K. J. Ruth, S. Litwin, H. Tuttle, J. S. Seldomridge, M. Rovito, D. Mintzer, R. Cohen and J. Treat, "Phase II Study of Paclitaxel, Carboplatin, and Cetuximab as First Line Treatment, for Patients with Advanced Non-Small Cell Lung Cancer (NSCLC): Results of OPN-017," Journal of Thoracic Oncology, Vol. 3, No. 11, 2008, pp. 1286-1292. doi:10.1097/JTO.0b013e318189f50e

[80] R. Rosell, G. Robinet, A. Szczesna, R. Ramlau, M. Constenla, B. C. Mennecier, W. Pfeifer, K. J. O’Byrne, T. Welte, R. Kolb, R. Pirker, A. Chemaissani, M. Perol, M. R. Ranson, P. A. Ellis, K. Pilz and M. Reck, "Randomized Phase II Study of Cetuximab plus Cisplatin/Vinorelbine Compared with Cisplatin/Vinorelbine Alone as First-Line Therapy in EGFR-Expressing Advanced NonSmall-Cell Lung Cancer," Annals of Oncology, Vol. 19, No. 2, 2008, pp. 362-369. doi:10.1093/annonc/mdm474

[81] R. S. Herbst, K. Kelly, K. Chansky, P. C. Mack, W. A. Franklin, F. R. Hirsch, J. N. Atkins, S. R. Dakhil, K. S. Albain, E. S. Kim, M. Redman, J. J. Crowley and D. R. Gandara, "Phase II Selection Design Trial of Concurrent Chemotherapy and Cetuximab versus Chemotherapy Followed by Cetuximab in Advanced-Stage Non-SmallCell Lung Cancer: Southwest Oncology Group Study S0342," Journal of Clinical Oncology, Vol. 28, No. 31, 2010, pp. 4747-4754. doi:10.1200/JCO.2009.27.9356

[82] C. Gridelli, A. Morabito, V. Gebbia, M. Mencoboni, F. Carrozza, M. G. Viganò, C. Verusio, R. Bollina, R. Mattioli, M. R. Valerio, G. Valmadre, P. Maione, A. Rossi, T. Cascone, F. Morgillo, M. Di Maio, M. C. Piccirillo, C. Gallo, F. Perrone and F. Ciardiello, "Cetuximab and Gemcitabine in Elderly or Adult PS2 Patients with Advanced Non-Small-Cell Lung Cancer: The Cetuximab in Advanced Lung Cancer (CALC1-E and CALC1-PS2) Randomized Phase II Trials," Lung Cancer, Vol. 67, No. 1, 2010, pp. 86-92. doi:10.1016/j.lungcan.2009.03.021

[83] D. R. Spigel, F. A. Greco, D. S. Thompson, C. Webb, J. Rubinsak, R. C. Inhorn, J. Reeves Jr., E. R. Vazquez, C. 
M. Lane, H. A. Burris III and J. D. Hainsworth, "Phase II Study of Cetuximab, Docetaxel, and Gemcitabine in Patients with Previously Untreated Advanced Non-SmallCell Lung Cancer," Clinical Lung Cancer, Vol. 11, No. 3, 2010, pp. 198-203. doi:10.3816/CLC.2010.n.026

[84] Y. Cao, C. Liao, A. Tan, L. Liu and F. Gao, "MetaAnalysis of Incidence and Risk of Hypomagnesemia with Cetuximab for Advanced Cancer," Chemotherapy, Vol. 56, No. 6, 2010, pp. 459-465. doi:10.1159/000321011

[85] R. Pirker, J. R. Pereira, A. Szczesna, J. von Pawel, M. Krzakowski, R. Ramlau, I. Vynnychenko, K. Park, C.-T. $\mathrm{Yu}$, V. Ganul, J.-K. Roh, E. Bajetta, K. O’Byrne, F. de Marinis, W. Eberhardt, T. Goddemeier, M. Emig and U. Gatzemeier, "Cetuximab plus Chemotherapy in Patients with Advanced Non-Small-Cell Lung Cancer (FLEX): An Open-Label Randomised Phase III Trial," Lancet, Vol. 373, No. 9674, 2009, pp. 1525-1531. doi:10.1016/S0140-6736(09)60569-9

[86] T. J. Lynch, T. Patel, L. Dreisbach, M. McCleod, W. J. Heim, R. C. Hermann, E. Paschold, N. O. Iannotti, S. Dakhil, S. Gorton, V. Pautret, M. R. Weber and D. Woytowitz, "Cetuximab and First-Line Taxane/Carboplatin Chemotherapy in Advanced Non-Small-Cell Lung Cancer: Results of the Randomized Multicenter Phase III Trial BMS099," Journal of Clinical Oncology, Vol. 28, No. 6, 2010, pp. 911-917. doi:10.1200/JCO.2009.21.9618

[87] S. Huang, E. A. Armstrong, S. Benavente, P. Chinnaiyan and P. M. Harari, "Dual-Agent Molecular Targeting of the Epidermal Growth Factor Receptor (EGFR): Combining Anti-EGFR Antibody with Tyrosine Kinase Inhibitor," Cancer Research, Vol. 64, No. 15, 2004, pp. 5355-5362. doi:10.1158/0008-5472.CAN-04-0562

[88] T. Cascone, M. P. Morelli, F. Morgillo, W.-Y. Kim, G. Rodolico, S. Pepe, G. Tortora, L. Berrino, H.-Y. Lee, J. V. Heymach and F. Ciardiello, "Synergistic Anti-Proliferative and Pro-Apoptotic Activity of Combined Therapy with Bortezomib, a Proteasome Inhibitor, with Anti-Epidermal Growth Factor Receptor (EGFR) Drugs in Human Cancer Cells," Journal of Cellular Physiology, Vol. 216, No. 3, 2008, pp. 698-707. doi:10.1002/jcp.21444

[89] P. Matar, F. Rojo, R. Cassia, G. Moreno-Bueno, S. Di Cosimo, J. Tabernero, M. Guzmán, S. Rodriguez, J. Arribas, J. Palacios and J. Baselga, "Combined Epidermal Growth Factor Receptor Targeting with the Tyrosine Kinase Inhibitor Gefitinib (ZD1839) and the Monoclonal Antibody Cetuximab (IMC-C225): Superiority over Single-Agent Receptor Targeting," Clinical Cancer Research, Vol. 10, No. 19, 2004, pp. 6487-6501. doi:10.1158/1078-0432.CCR-04-0870

[90] A. Z. Dudek, K. Lesniewski-Kmak, N. J. Shehadeh, O. N. Pandey, M. Franklin, R. A. Kratzke, E. W. Greeno and P. Kumar, "Phase I Study of Bortezomib and Cetuximab in Patients with solid tumours expressing epidermal growth factor receptor," British Journal of Cancer, Vol. 100, No. 9, 2009, pp. 1379-1384. doi:10.1038/sj.bjc.6605043

[91] M. J. Guarino, C. J. Schneider, M. A. Hosford, J. R. Brahmer, C. M. Rudin, F. G. Finckenstein, R. E. PhilipNorton, H. Lu, M. R. Weber and D. S. Ettinger, "Dual Inhibition of the Epidermal Growth Factor Receptor Pathway with Cetuximab and Erlotinib: A Phase I Study in Patients with Advanced Solid Malignancies," Oncologist, Vol. 14, No. 2, 2009, pp. 119-124.

doi:10.1634/theoncologist.2008-0124

[92] S. Ramalingam, J. Forster, C. Naret, T. Evans, M. Sulecki, H. Lu, P. Teegarden, M. R. Weber and C. P. Belani, "Dual Inhibition of the Epidermal Growth Factor Receptor with Cetuximab, an IgG1 Monoclonal Antibody, and Gefitinib, a Tyrosine Kinase Inhibitor, in Patients with Refractory Non-Small Cell Lung Cancer (NSCLC): A Phase I Study," Journal of Thoracic Oncology, Vol. 3, No. 3, 2008, pp. 258-264. doi:10.1097/JTO.0b013e3181653d1b

[93] J. W. Neal, R. S. Heist, P. Fidias, J. S. Temel, M. Huberman, J. P. Marcoux, A. Muzikansky, T. J. Lynch and L. V. Sequist, "Cetuximab Monotherapy in Patients with Advanced Non-Small Cell Lung Cancer after Prior Epidermal Growth Factor Receptor Tyrosine Kinase Inhibitor Therapy," Journal of Thoracic Oncology, Vol. 5, No. 11, 2010, pp. 1855-1858.

doi:10.1097/JTO.0b013e3181f0bee0

[94] "Chemotherapy in Non-Small Cell Lung Cancer: A Meta-Analysis Using Updated Data on Individual Patients from 52 Randomised Clinical Trials. Non-Small Cell Lung Cancer Collaborative Group," BMJ, Vol. 311, No. 7010, 1995, pp. 899-909. doi:10.1136/bmj.311.7010.899

[95] J. A. Bonner, P. M. Harari, J. Giralt, N. Azarnia, D. M. Shin, R. B. Cohen, C. U. Jones, R. Sur, D. Raben, J. Jassem, R. Ove, M. S. Kies, J. Baselga, H. Youssoufian, N. Amellal, E. K. Rowinsky and K. K. Ang, "Radiotherapy plus Cetuximab for Squamous-Cell Carcinoma of the Head and Neck," New England Journal of Medicine, Vol. 354, No. 6, 2006, pp. 567-578.

doi:10.1056/NEJMoa053422

[96] S. Hughes, J. Liong, A. Miah, S. Ahmad, M. Leslie, P. Harper, J. Prendiville, J. Shamash, R. Subramaniam, A. Gaya, J. Spicer and D. Landau, "A Brief Report on the Safety Study of Induction Chemotherapy Followed by Synchronous Radiotherapy and Cetuximab in Stage III Non-Small Cell Lung Cancer (NSCLC): SCRATCH Study," Journal of Thoracic Oncology, Vol. 3, No. 6, 2008, pp. 648-651. doi:10.1097/JTO.0b013e3181757a60

[97] National Cancer Institute (NCI), North Central Cancer Treatment Group, Cancer and Leukemia Group B, "HighDose Or Standard-Dose Radiation Therapy and Chemotherapy with or without Cetuximab in Treating Patients with Newly Diagnosed Stage iii Non-Small Cell Lung Cancer That Cannot Be Removed by Surgery," National Library of Medicine (US), ClinicalTrials.gov., Bethesda, 2000 .

http://clinicaltrials.gov/show/NCT00533949NLMIdentifi er: NCT00533949

[98] A. Jatoi, S. E. Schild, N. Foster, G. T. Henning, K. J. Dornfeld, P. J. Flynn, T. R. Fitch, S. R. Dakhil, K. M. Rowland, P. J. Stella, G. S. Soori and A. Adjei, "A Phase II Study of Cetuximab and Radiation in Elderly and/or Poor Performance Status Patients with Locally Advanced Non-Small-Cell Lung Cancer (N0422)," Annals of Oncology, Vol. 21, No. 10, 2010, pp. 2040-2044. doi:10.1093/annonc/mdq075 
[99] A. Hallqvist, G. Wagenius, H. Rylander, O. Brodin, E. Holmberg, B. Lödén, S.-B. Ewers, S. Bergström, G. Wichardt-Johansson, K. Nilsson, L. Ekberg, C. Sederholm and J. Nyman, "Concurrent Cetuximab and Radiotherapy after Docetaxel-Cisplatin Induction Chemotherapy in Stage III NSCLC: Satellite-A Phase II Study from the Swedish Lung Cancer Study Group," Lung Cancer, Vol. 71, No. 2, 2011, pp. 166-172. doi:10.1016/j.lungcan.2010.05.011

[100] A. D. Jensen, M. W. Münter, H. Bischoff, R. Haselmann, C. Timke, R. Krempien, F. Sterzing, S. Nill, S. Heeger, A. Hoess, U. Haberkorn, P. E. Huber, M. Steins, M. Thomas, J. Debus and K. K. Herfarth, "Treatment of Non-Small Cell Lung Cancer with Intensity-Modulated Radiation Therapy in Combination with Cetuximab: The NEAR Protocol (NCT00115518)," BMC Cancer, Vol. 6, 2006, p. 122. doi:10.1186/1471-2407-6-122

[101] G. R. Blumenschein Jr., R. Paulus, W. J. Curran, F. Robert, F. Fossella, M. Werner-Wasik, R. S. Herbst, P. O. Doescher, H. Choy and R. Komaki, "Phase II Study of Cetuximab in Combination with Chemoradiation in $\mathrm{Pa}-$ tients with Stage IIIA/B Non-Small-Cell Lung Cancer: RTOG 0324," Journal of Clinical Oncology, Vol. 29, No. 17, 2011, pp. 2312-2318. doi:10.1200/JCO.2010.31.7875

[102] R. Govindan, J. Bogart, T. Stinchcombe, X. Wang, L. Hodgson, R. Kratzke, J. Garst, T. Brotherton and E. E. Vokes, "Randomized Phase II Study of Pemetrexed, Carboplatin, and Thoracic Radiation with or without Cetuximab in Patients with Locally Advanced Unresectable Non-Small-Cell Lung Cancer: Cancer and Leukemia Group B Trial 30407," Journal of Clinical Oncology, Vol. 29, No. 23, 2011, pp. 3120-3125. doi:10.1200/JCO.2010.33.4979

[103] A. Maillet, L. Guilleminault, E. Lemarié, S. Lerondel, N. Azzopardi, J. Montharu, N. Congy-Jolivet, P. Reverdiau, B. Legrain, C. Parent, D.-H. Douvin, J. Hureaux, Y. Courty, M. De Monte, P. Diot, G. Paintaud, A. Le Pape, H. Watier and N. Heuzé-Vourc'h, "The Airways, a Novel Route for Delivering Monoclonal Antibodies to Treat Lung Tumors," Pharmaceutical Research, Vol. 28, No. 9, 2011, pp. 2147-2156. doi:10.1007/s11095-011-0442-5

[104] C. J. Allegra, J. M. Jessup, M. R. Somerfield, S. R. Hamilton, E. H. Hammond, D. F. Hayes, P. K. McAllister, R. F. Morton and R. L. Schilsky, "American Society of Clinical Oncology Provisional Clinical Opinion: Testing for KRAS Gene Mutations in Patients with Metastatic Colorectal Carcinoma to Predict Response to Anti-Epidermal Growth Factor Receptor Monoclonal Antibody Therapy," Journal of Clinical Oncology, Vol. 27, No. 12, 2009, pp. 2091-2096. doi:10.1200/JCO.2009.21.9170

[105] S. Khambata-Ford, C. T. Harbison, L. L. Hart, M. Awad, L.-A. Xu, C. E. Horak, S. Dakhil, R. C. Hermann, T. J. Lynch and M. R. Weber, "Analysis of Potential Predictive Markers of Cetuximab Benefit in BMS099, a Phase III Study of Cetuximab and First-Line Taxane/Carboplatin in Advanced Non-Small-Cell Lung Cancer," Journal of Clinical Oncology, Vol. 28, No. 6, 2010, pp. 918927. doi:10.1200/JCO.2009.25.2890

[106] R. Pirker, J. R. Pereira, J. von Pawel, M. Krzakowski, R. Ramlau, K. Park, F. de Marinis, W. E. E. Eberhardt, L.
Paz-Ares, S. Störkel, K.-M. Schumacher, A. von Heydebreck, I. Celik and K. J. O’Byrne, "EGFR Expression as a Predictor of Survival for First-Line Chemotherapy plus Cetuximab in Patients with Advanced Non-Small-Cell Lung Cancer: Analysis of Data from the Phase 3 FLEX Study," Lancet Oncology, Vol. 13, No. 1, 2012, pp. 3342. doi:10.1016/S1470-2045(11)70318-7

[107] U. Gatzemeier, J. von Pawel, I. Vynnychenko, P. Zatloukal, F. de Marinis, W. E. E. Eberhardt, L. Paz-Ares, K.-M. Schumacher, T. Goddemeier, K. J. O'Byrne and R. Pirker, "First-Cycle Rash and Survival in Patients with Advanced Non-Small-Cell Lung Cancer Receiving Cetuximab in Combination with First-Line Chemotherapy: A Subgroup Analysis of Data from the FLEX Phase 3 Study," Lancet Oncology, Vol. 12, No. 1, 2011, pp. 30-37. doi:10.1016/S1470-2045(10)70278-3

[108] M. A. Socinski, "Antibodies to the Epidermal Growth Factor Receptor in Non Small Cell Lung Cancer: Current Status of Matuzumab and Panitumumab," Clinical Cancer Research, Vol. 13, No. 15, 2007, pp. s4597-s4601. doi:10.1158/1078-0432.CCR-07-0335

[109] U. Vanhoefer, M. Tewes, F. Rojo, O. Dirsch, N. Schleucher, O. Rosen, J. Tillner, A. Kovar, A. H. Braun, T. Trarbach, S. Seeber, A. Harstrick and J. Baselga, "Phase I Study of the Humanized Antiepidermal Growth Factor Receptor Monoclonal Antibody EMD72000 in Patients with Advanced Solid Tumors That Express the Epidermal Growth Factor Receptor," Journal of Clinical Oncology, Vol. 22, No. 1, 2004, pp. 175-184. doi:10.1200/JCO.2004.05.114

[110] M. M. Schittenhelm, C. Kollmannsberger, K. Oechsle, A. Harlow, J. Morich, F. Honecker, R. Kurek, S. Störkel, L. Kanz, C. L. Corless, K.-K. Wong, C. Bokemeyer and M. C. Heinrich, "Molecular Determinants of Response to Matuzumab in Combination with Paclitaxel for Patients with Advanced Non-Small Cell Lung Cancer," Molecular Cancer Therapeutics, Vol. 8, No. 3, 2009, pp. 481-489. doi:10.1158/1535-7163.MCT-08-1068

[111] J. H. Schiller, J. von Pawel, P. Schütt, R. H. Ansari, M. Thomas, M. Saleh, R. D. McCroskey, W. Pfeifer, T. A. Marsland, G. H. Kloecker, M. Sebastian, R. Pirker, R. Kurek, C. Beadman and M. A. Socinski, "Pemetrexed with or without Matuzumab as Second-Line Treatment for Patients with Stage IIIB/IV Non-Small Cell Lung Cancer," Journal of Thoracic Oncology, Vol. 5, No. 12, 2010, pp. 1977-1985. doi:10.1097/JTO.0b013e3181f4a5c9

[112] C. Mateo, E. Moreno, K. Amour, J. Lombardero, W. Harris and R. Pérez, "Humanization of a Mouse Monoclonal Antibody That Blocks the Epidermal Growth Factor Receptor: Recovery of Antagonistic Activity," Immunotechnology, Vol. 3, No. 1, 1997, pp. 71-81. doi:10.1016/S1380-2933(97)00065-1

[113] G. Bebb, C. Smith, S. Rorke, W. Boland, L. Nicacio, R. Sukhoo and A. Brade, "Phase I Clinical Trial of the AntiEGFR Monoclonal Antibody Nimotuzumab with Concurrent External Thoracic Radiotherapy in Canadian Patients Diagnosed with Stage IIb, III or IV Non-Small Cell Lung Cancer Unsuitable for Radical Therapy," Cancer Chemotherapy and Pharmacology, Vol. 67, No. 4, 2011, 
pp. 837-845. doi:10.1007/s00280-010-1379-9

[114] H. J. Choi, J. H. Sohn, C. G. Lee, H. S. Shim, I.-J. Lee, W. I. Yang, J. E. Kwon, S. K. Kim, M.-S. Park, J. H. Lee and J. H. Kim, "A Phase I Study of Nimotuzumab in Combination with Radiotherapy in Stages IIB-IV Non-Small Cell Lung Cancer Unsuitable for Radical Therapy: Korean Results," Lung Cancer, Vol. 71, No. 1, 2011, pp. 55-59. doi:10.1016/j.lungcan.2010.04.010

[115] B. C. Cho, Yonsei University, "Phase II Study of Gefitinib plus Nimotuzumab versus Gefitinib in Non-Small Cell Lung Cancer (DATE)" National Library of Medicine (US), ClinicalTrials.gov, Bethesda, 2000.

http://clinicaltrials.gov/show/NCT01498562 NLM Identifier: NCT01498562

[116] Biotech Pharmaceutical Co., Ltd. Yanzhao, Tianjin Medical University Cancer Institute and Hospital, "Nimotuzumab in Combination with Paclitaxel Liposome and Carboplatin (TP Regimen) for the Advanced NSCLC Patients," National Library of Medicine (US), ClinicalTrials.gov, Bethesda, 2000.

http://clinicaltrials.gov/show/NCT01393080 NLM Identifier: NCT01393080

[117] J. V. Heymach, M. Nilsson, G. Blumenschein, V. Papadimitrakopoulou and R. Herbst, "Epidermal Growth Factor Receptor Inhibitors in Development for the Treatment of Non-Small Cell Lung Cancer," Clinical Cancer Research, Vol. 12, No. 14, 2006, pp. 4441s-4445s. doi:10.1158/1078-0432.CCR-06-0286

[118] L. M. Weiner, A. S. Belldegrun, J. Crawford, A. W. Tolcher, P. Lockbaum, R. H. Arends, L. Navale, R. G. Amado, G. Schwab and R. A. Figlin, "Dose and Schedule Study of Panitumumab Monotherapy in Patients with Advanced Solid Malignancies," Clinical Cancer Research, Vol. 14, No. 2, 2008, pp. 502-508. doi:10.1158/1078-0432.CCR-07-1509

[119] G. R. Blumenschein Jr., K. Reckamp, G. J. Stephenson, T. O’Rourke, G. Gladish, J. McGreivy, Y.-N. Sun, Y. Ye, M. Parson and A. Sandler, "Phase 1b Study of Motesanib, an Oral Angiogenesis Inhibitor, in Combination with Carboplatin/Paclitaxel and/or Panitumumab for the Treatment of Advanced Non-Small Cell Lung Cancer," Clinical Cancer Research, Vol. 16, No. 1, 2010, pp. 279-290. doi:10.1158/1078-0432.CCR-09-1675

[120] National Cancer Institute (NCI), "Chemotherapy and Radiation Therapy with or without Panitumumab in Treating Patients with Stage IIIA Non-Small Cell Lung Cancer," National Library of Medicine (US), ClinicalTrials.gov, Bethesda, 2000.

http:/clinicaltrials.gov/show/NCT00979212NLMIdentifi er NCT00979212

[121] Vejle Hospital, "First-Line Chemotherapy and Panitumumab in Advanced Non-Small Cell Lung Cancer (LungTRIO)," National Library of Medicine (US), ClinicalTrials.gov, Bethesda, 2000.

http:/clinicaltrials.gov/show/NCT01038037NLMIdentifi er NCT01038037

[122] Gesellschaft fur Medizinische Innovation-Hamatologie und Onkologie mbH. WiSP Wissenschaftlicher Service Pharma GmbH, "Panitumumab plus Pemetrexed and Cis- platin (PemCisP) versus PemCis in the First-Line Treatment of Patients with Non-Small Cell Lung Cancer," National Library of Medicine (US), ClinicalTrials.gov, Bethesda, 2000.

http://clinicaltrials.gov/show/NCT01088620NLMIdentifi er NCT01088620

[123] B. Kuenen, P. O. Witteveen, R. Ruijter, G. Giaccone, A. Dontabhaktuni, F. Fox, T. Katz, H. Youssoufian, J. Zhu, E. K. Rowinsky and E. E. Voest, "A Phase I Pharmacologic Study of Necitumumab (IMC-11F8), a Fully Human IgG1 Monoclonal Antibody Directed against EGFR in Patients with Advanced Solid Malignancies,"Clinical Cancer Research, Vol. 16, No. 6, 2010, pp. 1915-1923. doi:10.1158/1078-0432.CCR-09-2425

[124] ImClone LLC, Parexel, "First-Line Treatment of Participants with Stage IV Squamous Non-Small Cell Lung Cancer with Necitumumab and Gemcitabine-Cisplatin (SQUIRE)," National Library of Medicine (US), ClinicalTrials.gov, Bethesda, 2000.

http://clinicaltrials.gov/show/NCT00981058 NLM Identifier NCT00981058

[125] Parexel. PPD, Medidata Solutions, Laboratory Corporation of America, University of Colorado, Denver, Thermo Fisher Scientific, ImClone LLC., "First-Line Treatment of Patients with Stage iv Nonsquamous Non-Small Cell Lung Cancer with Necitumumab (IMC-11F8) and Pemetrexed-Cisplatin (INSPIRE)," National Library of Medicine (US), ClinicalTrials.gov, Bethesda, 2000.

http:/clinicaltrials.gov/show/NCT00982111 NLM Identifier: NCT00982111

[126] Lilly, "Bristol-Myers Squibb Stop Enrollment in One of Two Phase III Lung Cancer Trials of Necitumumab," Bristol-Myers Squibb, Princeton, 2011.

http://www.bms.com/news/press_releases/pages/default.a spx?RSSLink=http://www.businesswire.com/news/bms/2 0110202006011/en\&t=634322838509124725).

[127] M. M. Goldenberg, “Trastuzumab, a Recombinant DNADerived Humanized Monoclonal Antibody, a Novel Agent for the Treatment of Metastatic Breast Cancer," Clinical Therapeutics, Vol. 21, No. 2, 1999, pp. 309-318. doi:10.1016/S0149-2918(00)88288-0

[128] F. R. Hirsch, B. Helfrich, W. A. Franklin, M. VarellaGarcia, D. C. Chan and P. A. Bunn Jr., "Preclinical Studies of Gemcitabine and Trastuzumab in Breast and Lung Cancer Cell Lines," Clinical Breast Cancer, Vol. 3, Suppl 1, 2002, pp. 12-16. doi:10.3816/CBC.2002.s.003

[129] P. N. Lara Jr., L. Laptalo, J. Longmate, D. H. M. Lau, R. Gandour-Edwards, P. H. Gumerlock, J. H. Doroshow and D. R. Gandara, "Trastuzumab plus Docetaxel in HER2/ Neu-Positive Non-Small-Cell Lung Cancer: A California Cancer Consortium Screening and Phase II Trial," Clinical Lung Cancer, Vol. 5, No. 4, 2004, pp. 231-236. doi:10.3816/CLC.2004.n.004

[130] G. Clamon, J. Herndon, J. Kern, R. Govindan, J. Garst, D. Watson and M. Green, "Lack of Trastuzumab Activity in Nonsmall Cell Lung Carcinoma with Overexpression of erb-B2: 39810: A Phase II Trial of Cancer and Leukemia Group B," Cancer, Vol. 103, No. 8, 2005, pp. 1670-1675. doi:10.1002/cncr.20950 
[131] C. J. Langer, P. Stephenson, A. Thor, M. Vangel and D. H. Johnson, "Trastuzumab in the Treatment of Advanced Non-Small-Cell Lung Cancer: Is There a Role? Focus on Eastern Cooperative Oncology Group Study 2598," Journal of Clinical Oncology, Vol. 22, No. 7, 2004, pp. 11801187. doi:10.1200/JCO.2004.04.105

[132] R. G. Zinner, B. S. Glisson, F. V. Fossella, K. M. W. Pisters, M. S. Kies, P. M. Lee, E. Massarelli, B. Sabloff, H. A. Fritsche Jr., J. Y. Ro, N. G. Ordonez, H. T. Tran, Y. Yang, T. L. Smith, R. D. Mass and R. S. Herbst, "Trastuzumab in Combination with Cisplatin and Gemcitabine in Patients with Her2-Overexpressing, Untreated, Advanced Non-Small Cell Lung Cancer: Report of a Phase II Trial and Findings Regarding Optimal Identification of Patients with Her2-Overexpressing Disease," Lung Cancer, Vol. 44, No. 1, 2004, pp. 99-110. doi:10.1016/j.lungcan.2003.09.026

[133] U. Gatzemeier, G. Groth, C. Butts, N. Van Zandwijk, F. Shepherd, A. Ardizzoni, C. Barton, P. Ghahramani and V. Hirsh, "Randomized Phase II Trial of Gemcitabine-Cisplatin with or without Trastuzumab in HER2-Positive Non-Small-Cell Lung Cancer," Annals of Oncology, Vol. 15, No. 1, 2004, pp. 19-27. doi:10.1093/annonc/mdh031

[134] M. C. Franklin, K. D. Carey, F. F. Vajdos, D. J. Leahy, A. M. de Vos and M. X. Sliwkowski, "Insights into ErbB Signaling from the Structure of the ErbB2-Pertuzumab Complex," Cancer Cell, Vol. 5, No. 4, 2004, pp. 317-328. doi:10.1016/S1535-6108(04)00083-2

[135] K. Sakai, H. Yokote, K. Murakami-Murofushi, T. Tamura, N. Saijo and K. Nishio, "Pertuzumab, a Novel HER Dimerization Inhibitor, Inhibits the Growth of Human Lung Cancer Cells Mediated by the HER3 Signaling Pathway," Cancer Science, Vol. 98, No. 9, 2007, pp. 1498-1503. doi:10.1111/j.1349-7006.2007.00553.x

[136] R. S. Herbst, A. M. Davies, R. B. Natale, T. P. Dang, J. H. Schiller, L. L. Garland, V. A. Miller, D. Mendelson, A. D. Van den Abbeele, Y. Melenevsky, D. J. de Vries, D. A. Eberhard, B. Lyons, S. G. Lutzker and B. E. Johnson, "Efficacy and Safety of Single-Agent Pertuzumab, a Human Epidermal Receptor Dimerization Inhibitor, in Patients with Non Small Cell Lung Cancer," Clinical Cancer Research, Vol. 13, No. 20, 2007, pp. 6175-6181. doi:10.1158/1078-0432.CCR-07-0460

[137] A. G. Roche Pharma and A. Genentech, "Study of the Combination of Erlotinib and Pertuzumab in Patients with Relapsed Non-Small Cell Lung Cancer (PENGUIN)," National Library of Medicine (US), ClinicalTrials.gov, Bethesda, 2000.

http://clinicaltrials.gov/show/NCT00855894 NLM Identifier: NCT00855894

[138] S. L. Topalian, G. J. Weiner and D. M. Pardoll, "Cancer Immunotherapy Comes of Age," Journal of Clinical Oncology, Vol. 29, No. 36, 2011, pp. 4828-4836. doi:10.1200/JCO.2011.38.0899

[139] S. G. Holtan and D. J. Creedon, "Mother Knows Best: Lessons from Fetomaternal Tolerance Applied to Cancer Immunity," Frontiers in Bioscience, Vol. 3, 2011, pp. 1533-1540. doi: $10.2741 / 243$

[140] I. Mellman, G. Coukos and G. Dranoff, "Cancer Immu- notherapy Comes of Age," Nature, Vol. 480, No. 7378 , 2011, pp. 480-489. doi:10.1038/nature10673

[141] L. H. Camacho, "Novel Therapies Targeting the Immune System: CTLA4 Blockade with Tremelimumab (CP675,206), a Fully Human Monoclonal Antibody," Expert Opinion on Investigational Drugs, Vol. 17, No. 3, 2008, pp. 371-385. doi:10.1517/13543784.17.3.371

[142] H. Dong, S. E. Strome, D. R. Salomao, H. Tamura, F. Hirano, D. B. Flies, P. C. Roche, J. Lu, G. Zhu, K. Tamada, V. A. Lennon, E. Celis and L. Chen, "TumorAssociated B7-H1 Promotes T-Cell Apoptosis: A Potential Mechanism of Immune Evasion," Nature Medicine, Vol. 8, No. 8, 2002, pp. 793-800.

[143] J. Konishi, K. Yamazaki, M. Azuma, I. Kinoshita, H. Dosaka-Akita and M. Nishimura, "B7-H1 Expression on Non-Small Cell Lung Cancer Cells and Its Relationship with Tumor-Infiltrating Lymphocytes and Their PD-1 Expression," Clinical Cancer Research, Vol. 10, No. 15, 2004, pp. 5094-5100. doi:10.1158/1078-0432.CCR-04-0428

[144] T. J. Lynch, I. Bondarenko, A. Luft, P. Serwatowski, F. Barlesi, R. Chacko, M. Sebastian, J. Neal, H. Lu, J.-M. Cuillerot and M. Reck, "Ipilimumab in Combination with Paclitaxel and Carboplatin as First-Line Treatment in Stage IIIB/IV Non-Small-Cell Lung Cancer: Results from a Randomized, Double-Blind, Multicenter Phase II Study," Journal of Clinical Oncology, Vol. 30, No. 17, 2012, pp. 2046-2054. doi:10.1200/JCO.2011.38.4032

[145] B.-M. Squibb, “Trial in Squamous Non Small Cell Lung Cancer Subjects Comparing Ipilimumab plus Paclitaxel and Carboplatin versus Placebo Plus Paclitaxel and Carboplatin," National Library of Medicine (US), ClinicalTrials.gov, Bethesda, 2000.

http://clinicaltrials.gov/show/NCT01285609 NLM Identifier NCT01285609

[146] Pfizer, "Randomized Study of CP-675,206 or Best Supportive Care Immediately after Platinum-Based Therapy for Non-Small Cell Lung Cancer (NSCLC)," National Library of Medicine (US), ClinicalTrials.gov, Bethesda, 2000.

http://clinicaltrials.gov/show/NCT00312975NLMIdentifi er NCT00312975

[147] J. R. Brahmer, C. G. Drake, I. Wollner, J. D. Powderly, J. Picus, W. H. Sharfman, E. Stankevich, A. Pons, T. M. Salay, T. L. McMiller, M. M. Gilson, C. Wang, M. Selby, J. M. Taube, R. Anders, L. Chen, A. J. Korman, D. M. Pardoll, I. Lowy and S. L. Topalian, "Phase I Study of Single-Agent Anti-Programmed Death-1 (MDX-1106) in Refractory Solid Tumors: Safety, Clinical Activity, Pharmacodynamics, and Immunologic Correlates," Journal of Clinical Oncology, Vol. 28, No. 19, 2010, pp. 3167-3175. doi:10.1200/JCO.2009.26.7609

[148] S. L. Topalian, F. S. Hodi, J. R. Brahmer, S. N. Gettinger, D. C. Smith, D. F. McDermott, J. D. Powderly, R. D. Carvajal, J. A. Sosman, M. B. Atkins, P. D. Leming, D. R. Spigel, S. J. Antonia, L. Horn, C. G. Drake, D. M. Pardoll, L. Chen, W. H. Sharfman, R. A. Anders, J. M. Taube, T. L. McMiller, H. Xu, A. J. Korman, M. Jure-Kunkel, S. Agrawal, D. McDonald, G. D. Kollia, A. Gupta, J. M. Wigginton and M. Sznol, "Safety, Activity, and Immune 
Correlates of Anti-PD-1 Antibody in Cancer," New England Journal of Medicine, Vol. 366, No. 26, 2012, pp. 2443-2454. doi:10.1056/NEJMoa1200690

[149] J. R. Brahmer, S. S. Tykodi, L. Q. M. Chow, W.-J. Hwu, S. L. Topalian, P. Hwu, C. G. Drake, L. H. Camacho, J. Kauh, K. Odunsi, H. C. Pitot, O. Hamid, S. Bhatia, R. Martins, K. Eaton, S. Chen, T. M. Salay, S. Alaparthy, J. F. Grosso, A. J. Korman, S. M. Parker, S. Agrawal, S. M. Goldberg, D. M. Pardoll, A. Gupta and J. M. Wigginton, "Safety and Activity of Anti-PD-L1 Antibody in Patients with Advanced Cancer," New England Journal of Medicine, Vol. 366, No. 26, 2012, pp. 2455-2465. doi:10.1056/NEJMoa1200694

[150] G. Fürstenberger and H.-J. Senn, "Insulin-Like Growth Factors and Cancer," Lancet Oncology, Vol. 3, No. 5, 2002, pp. 298-302. doi:10.1016/S1470-2045(02)00731-3

[151] H. Yu, M. R. Spitz, J. Mistry, J. Gu, W. K. Hong and X. Wu, "Plasma Levels of Insulin-Like Growth Factor-I and Lung Cancer Risk: A Case-Control Analysis," Journal of the National Cancer Institute, Vol. 91, No. 2, 1999, pp. 151-156. doi:10.1093/jnci/91.2.151

[152] F. Morgillo, W.-Y. Kim, E. S. Kim, F. Ciardiello, W. K. Hong and H.-Y. Lee, "Implication of the Insulin-Like Growth Factor-IR Pathway in the Resistance of NonSmall Cell Lung Cancer Cells to Treatment with Gefitinib," Clinical Cancer Research, Vol. 13, No. 9, 2007, pp. 2795-2803. doi:10.1158/1078-0432.CCR-06-2077

[153] M. Nakagawa, H. Uramoto, S. Oka, Y. Chikaishi, T. Iwanami, H. Shimokawa, T. So, T. Hanagiri and F. Tanaka, "Clinical Significance of IGF1R Expression in NonSmall-Cell Lung Cancer," Clinical Lung Cancer, Vol. 13, No. 2, 2012, pp. 136-142. doi:10.1016/j.cllc.2011.10.006

[154] L. R. Molife, P. C. Fong, L. Paccagnella, A. H. M. Reid, H. M. Shaw, L. Vidal, H.-T. Arkenau, V. Karavasilis, T. A. Yap, D. Olmos, J. Spicer, S. Postel-Vinay, D. Yin, A. Lipton, L. Demers, K. Leitzel, A. Gualberto and J. S. de Bono, "The Insulin-Like Growth Factor-I Receptor Inhibitor Figitumumab (CP-751,871) in Combination with Docetaxel in Patients with Advanced Solid Tumours: Results of a Phase Ib Dose-Escalation, Open-Label Study," British Journal of Cancer, Vol. 103, No. 3, 2010, pp. 332-339. doi:10.1038/sj.bjc.6605767

[155] D. D. Karp, L. G. Paz-Ares, S. Novello, P. Haluska, L. Garland, F. Cardenal, L. J. Blakely, P. D. Eisenberg, C. J. Langer, G. Blumenschein Jr., F. M. Johnson, S. Green and A. Gualberto, "Phase II Study of the Anti-InsulinLike Growth Factor Type 1 Receptor Antibody CP751,871 in Combination with Paclitaxel and Carboplatin in Previously Untreated, Locally Advanced, or Metastatic Non-Small-Cell Lung Cancer," Journal of Clinical Oncology, Vol. 27, No. 15, 2009, pp. 2516-2522. doi:10.1200/JCO.2008.19.9331

[156] D. D. Karp, M. N. Pollak, R. B. Cohen, P. D. Eisenberg, P. Haluska, D. Yin, A. Lipton, L. Demers, K. Leitzel, M. L. Hixon, L. W. Terstappen, L. Garland, L. G. Paz-Ares, F. Cardenal, C. J. Langer and A. Gualberto, "Safety, Pharmacokinetics, and Pharmacodynamics of the InsulinLike Growth Factor Type 1 Receptor Inhibitor Figitumumab (CP-751,871) in Combination with Paclitaxel and Carboplatin," Journal of Thoracic Oncology, Vol. 4, No.
11, 2009, pp. 1397-1403. doi:10.1097/JTO.0b013e3181ba2f1d

[157] A. Gualberto, M. L. Hixon, D. D. Karp, D. Li, S. Green, M. Dolled-Filhart, L. G. Paz-Ares, S. Novello, J. Blakely, C. J. Langer and M. N. Pollak, "Pre-Treatment Levels of Circulating Free IGF-1 Identify NSCLC Patients Who Derive Clinical Benefit from Figitumumab," British Journal of Cancer, Vol. 104, No. 1, 2011, pp. 68-74. doi:10.1038/sj.bjc.6605972

[158] Pfizer, "Carboplatin and Paclitaxel with or without CP-751, 871 (an IGF-1R inhibitor) for Advanced NSCLC of Squamous, Large Cell and Adenosquamous Carcinoma Histology," National Library of Medicine (US), ClinicalTrials.gov, Bethesda, 2000.

http://clinicaltrials.gov/show/NCT00596830 NLM Identifier: NCT00596830

[159] http://www.ascopost.com/articles/november-2010/figitum umab-fails-to-improve-survival,-increases-toxicities,-in-fi rst $\%$ E2\% $\% 0 \% 91$ line-treatment-of-patients-with-nsclc/

[160] Pfizer, "Trial of CP-751, 871 and Erlotinib in Refractory Lung Cancer (NSCLC)," National Library of Medicine (US), ClinicalTrials.gov, Bethesda, 2000. http://clinicaltrials.gov/show/NCT00673049 NLM Identifier: NCT00673049

[161] F. Atzori, J. Tabernero, A. Cervantes, L. Prudkin, J. Andreu, E. Rodríguez-Braun, A. Domingo, J. Guijarro, C. Gamez, J. Rodon, S. Di Cosimo, H. Brown, J. Clark, J. S. Hardwick, R. A. Beckman, W. D. Hanley, K. Hsu, E. Calvo, S. Roselló, R. B. Langdon and J. Baselga, "A Phase I Pharmacokinetic and Pharmacodynamic Study of Dalotuzumab (MK-0646), an Anti-Insulin-Like Growth Factor-1 Receptor Monoclonal Antibody, in Patients with Advanced Solid Tumors," Clinical Cancer Research, Vol. 17, No. 19, 2011, pp. 6304-6312. doi:10.1158/1078-0432.CCR-10-3336

[162] Merck, "A Study Evaluating Dalotuzumab (MK0646) in Combination with Erlotinib for Patients with Non-Small Cell Lung Cancer (0646-007)," National Library of Medicine (US), ClinicalTrials.gov, Bethesda, 2000. http:/clinicaltrials.gov/show/NCT00654420 NLM Identifier: NCT00654420

[163] Merck, University of Kansas, "MK-0646 Insulin Growth Factor 1 Receptor Antibody in Stage IIIb or IV Metastatic Non-Squamous Lung Cancer (IMPACT)," National Library of Medicine (US), ClinicalTrials.gov, Bethesda, 2000 .

http://clinicaltrials.gov/show/NCT00799240 NLM Identifier: NCT00799240

[164] National Cancer Institute (NCI), "Gemcitabine Hydrochloride and Carboplatin with or without MK-0646 as First-Line Therapy in Treating Patients with Stage IIIB or Stage IV Non-Small Cell Lung Cancer," National Library of Medicine (US), ClinicalTrials.gov, Bethesda, 2000. http://clinicaltrials.gov/show/NCT00951444 NLM Identifier: NCT00951444

[165] A. Weickhardt, R. Doebele, A. Oton, J. Lettieri, D. Maxson, M. Reynolds, A. Brown, M. K. Jackson, G. Dy, A. Adjei, G. Fetterly, X. Lu, W. Franklin, M. Varella-Garcia, F. R. Hirsch, M. W. Wynes, H. Youssoufian, A. Adjei 
and D. R. Camidge, "A Phase I/II Study of Erlotinib in Combination with the Anti-Insulin-Like Growth Factor-1 Receptor Monoclonal Antibody IMC-A12 (Cixutumumab) in Patients with Advanced Non-Small Cell Lung Cancer," Journal of Thoracic Oncology, Vol. 7, No. 2, 2012, pp. 419-426. doi:10.1097/JTO.0b013e31823c5b11

[166] National Cancer Institute (NCI), "Paclitaxel, Carboplatin, and Bevacizumab with or without Cixutumumab in Treating Patients with Stage IV or Recurrent Non-Small Cell Lung Cancer," National Library of Medicine (US), ClinicalTrials.gov, Bethesda, 2000.

http://clinicaltrials.gov/show/NCT00955305 NLM Identifier: NCT00955305

[167] ImClone LLC, “A Study of IMC-A12 (Cixutumumab) with and without Other Standard Chemotherapies in $\mathrm{Pa}$ tients with Lung Cancer Who Have Not Received Chemotherapy Before," National Library of Medicine (US), ClinicalTrials.gov, Bethesda, 2000.

http://clinicaltrials.gov/show/NCT00870870 NLM Identifier: NCT00870870

[168] National Cancer Institute (NCI), "Erlotinib with or without IMC-A12 in Treating Patients with Stage III or Stage IV Non-Small Cell Lung Cancer," National Library of Medicine (US), ClinicalTrials.gov, Bethesda, 2000. http://clinicaltrials.gov/show/NCT00778167 NLM Identifier: NCT00778167

[169] Biogen Idec, “A Study of BIIB022 in Combination with Paclitaxel and Carboplatin in Subjects with Non-Small Cell Lung Cancer," National Library of Medicine (US), ClinicalTrials.gov, Bethesda, 2000. http://clinicaltrials.gov/show/NCT00970580 NLM Identifier: NCT00970580

[170] S. S. Ramalingam, D. R. Spigel, D. Chen, M. B. Steins, J. A. Engelman, C.-P. Schneider, S. Novello, W. E. E. Eberhardt, L. Crino, K. Habben, L. Liu, P. A. Jänne, C. M. Brownstein and M. Reck, "Randomized Phase II Study of Erlotinib in Combination with Placebo or R1507, a Monoclonal Antibody to Insulin-Like Growth Factor-1 Receptor, for Advanced-Stage Non-Small-Cell Lung Cancer," Journal of Clinical Oncology, Vol. 29, No. 34, 2011, pp. 4574-4580. doi:10.1200/JCO.2011.36.6799

[171] Amgen, "Phase 1b/2 Study of AMG 479 in Combination with Paclitaxel and Carboplatin for 1st Line Treatment of Advanced Squamous Non-Small Cell Lung Cancer," National Library of Medicine (US), ClinicalTrials.gov, Bethesda, 2000.

http://clinicaltrials.gov/show/NCT00807612 NLM Identifier NCT00807612

[172] Amgen, "AMG 655 in Combination with AMG 479 in Advanced, Refractory Solid Tumors," National Library of Medicine (US), ClinicalTrials.gov, Bethesda, 2000. http://clinicaltrials.gov/show/NCT00819169 NLM Identifier: NCT00819169

[173] S. R. Wiley, K. Schooley, P. J. Smolak, W. S. Din, C. P. Huang, J. K. Nicholl, G. R. Sutherland, T. D. Smith, C. Rauch and C. A. Smith, "Identification and Characterization of a New Member of the TNF Family That Induces Apoptosis," Immunity, Vol. 3, No. 6, 1995, pp. 673-682. doi:10.1016/1074-7613(95)90057-8
[174] L. Pukac, P. Kanakaraj, R. Humphreys, R. Alderson, M. Bloom, C. Sung, T. Riccobene, R. Johnson, M. Fiscella, A. Mahoney, J. Carrell, E. Boyd, X. T. Yao, L. Zhang, L. Zhong, A. von Kerczek, L. Shepard, T. Vaughan, B. Edwards, C. Dobson, T. Salcedo and V. Albert, "HGSETR1, a Fully Human TRAIL-Receptor 1 Monoclonal Antibody, Induces Cell Death in Multiple Tumour Types in Vitro and in Vivo," British Journal of Cancer, Vol. 92, No. 8, 2005, pp. 1430-1441. doi:10.1038/sj.bjc.6602487

[175] D. C. J. Spierings, E. G. E. de Vries, W. Timens, H. J. M. Groen, H. M. Boezen and S. de Jong, "Expression of TRAIL and TRAIL Death Receptors in Stage III NonSmall Cell Lung Cancer Tumors," Clinical Cancer Research, Vol. 9, No. 9, 2003, pp. 3397-3405.

[176] W. A. Cooper, M. R. J. Kohonen-Corish, L. Zhuang, B. McCaughan, C. Kennedy, G. Screaton, R. L. Sutherland and C.-S. Lee, "Role and Prognostic Significance of Tumor Necrosis Factor-Related Apoptosis-Inducing Ligand Death Receptor DR5 in Nonsmall-Cell Lung Cancer and Precursor Lesions," Cancer, Vol. 113, No. 1, 2008, pp. 135-142. doi:10.1002/cncr.23528

[177] T. A. Luster, J. A. Carrell, K. McCormick, D. Sun and R. Humphreys, "Mapatumumab and Lexatumumab Induce Apoptosis in TRAIL-R1 and TRAIL-R2 Antibody-Resistant NSCLC Cell Lines When Treated in Combination with Bortezomib," Molecular Cancer Therapeutics, Vol. 8, No. 2, 2009, pp. 292-302. doi:10.1158/1535-7163.MCT-08-0918

[178] F. A. Greco, P. Bonomi, J. Crawford, K. Kelly, Y. Oh, W. Halpern, L. Lo, G. Gallant and J. Klein, "Phase 2 Study of Mapatumumab, a Fully Human Agonistic Monoclonal Antibody Which Targets and Activates the TRAIL Receptor-1, in Patients with Advanced Non-Small Cell Lung Cancer," Lung Cancer, Vol. 61, No. 1, 2008, pp. 82-90. doi:10.1016/j.lungcan.2007.12.011

[179] J. Von Pawel, J. H. Harvey, D. R. Spigel, M. Dediu, M. Reck, C. L. Cebotaru, E. Kumm, G. Gallant, N. Fox and D. R. Camidge, "A Randomized Phase II Trial of Mapatumumab, a TRAIL-R1 Agonist Monoclonal Antibody, in Combination with Carboplatin and Paclitaxel in Patients with Advanced NSCLC," Journal of Clinical Oncology, Vol. 28, No. 18, 2010.

[180] H. A. Wakelee, A. Patnaik, B. I. Sikic, M. Mita, N. L. Fox, R. Miceli, S. J. Ullrich, G. A. Fisher and A. W. Tolcher, "Phase I and Pharmacokinetic Study of Lexatumumab (HGS-ETR2) Given Every 2 Weeks in Patients with Advanced Solid Tumors," Annals of Oncology, Vol. 21, No. 2, 2010, pp. 376-381. doi:10.1093/annonc/mdp292

[181] R. S. Herbst, R. Kurzrock, D. S. Hong, M. Valdivieso, C.-P. Hsu, L. Goyal, G. Juan, Y. C. Hwang, S. Wong, J. S. Hill, G. Friberg and P. M. LoRusso, "A First-in-Human Study of Conatumumab in Adult Patients with Advanced Solid Tumors," Clinical Cancer Research, Vol. 16, No. 23, 2010, pp. 5883-5891. doi:10.1158/1078-0432.CCR-10-0631

[182] A. Forero-Torres, J. Shah, T. Wood, J. Posey, R. Carlisle, C. Copigneaux, F. R. Luo, S. Wojtowicz-Praga, I. Percent and M. Saleh, "Phase I Trial of Weekly Tigatuzumab, an Agonistic Humanized Monoclonal Antibody Targeting 
Death Receptor 5 (DR5)," Cancer Biother Radiopharm, Vol. 25, No. 1, 2010, pp. 13-19. doi:10.1089/cbr.2009.0673

[183] T. J. Bayliss, J. T. Smith, M. Schuster, K. H. Dragnev and J. R. Rigas, "A Humanized Anti-IL-6 Antibody (ALD518) in Non-Small Cell Lung Cancer," Expert Opinion on Biological Therapy, Vol. 11, No. 12, 2011, pp. 16631668. doi: $10.1517 / 14712598.2011 .627850$

[184] A. Mantovani, P. Allavena, A. Sica and F. Balkwill, "Cancer-Related Inflammation," Nature, Vol. 454, No. 7203, 2008, pp. 436-444. doi:10.1038/nature07205

[185] N. Songür, B. Kuru, F. Kalkan, C. Ozdilekcan, H. Cakmak and N. Hizel, "Serum Interleukin-6 Levels Cor- relate with Malnutrition and Survival in Patients with Advanced Non-Small Cell Lung Cancer," Tumori, Vol. 90, No. 2, 2004, pp. 196-200.

[186] J. R. Rigas, M. Schuster, S. V. Orlov, B. Milovanovic, B. K. Prabhash, J. T. Smith, et al., "Effect of ALD518, a Humanized Anti-IL-6 Antibody, on Lean Body Mass Loss and Symptoms in Patients with Advanced NonSmall Cell Lung Cancer (NSCLC): Results of a Phase II Randomized, Double-Blind Safety and Efficacy Trial," Journal of Clinical Oncology, Vol. 28, 2010, pp. A7622.

[187] M. Schuster, J. R. Rigas, S. V. Orlov, B. Milovanovic, K. Prabhash, J. T. Smith, et al., "ALD518, a Humanized Anti-IL-6 Antibody, Treats Anemia in Patients with Advanced Non-Small Cell Lung Cancer (NSCLC): Results of a Phase II, Randomized, Double-Blind, Placebo-Controlled Trial," Journal of Clinical Oncology, Vol. 28, 2010, Article ID: A7631.

[188] Y. N. Malykh, R. Schauer and L. Shaw, "N-GlycolyIneuraminic Acid in Human Tumours," Biochimie, Vol. 83, No. 7, 2001, pp. 623-634. doi:10.1016/S0300-9084(01)01303-7

[189] S. Alfonso, R. M. Diaz, A. de la Torre, E. Santiesteban, F. Aguirre, K. Pérez, J. L. Rodríguez, M. del C. Barroso, A. M. Hernández, D. Toledo, M. R. Gabri, D. F. Alonso, C. Viada, R. E. Gómez, E. Suárez, A. M. Vazquez, R. Perez and A. E. Macias, "1E10 Anti-Idiotype Vaccine in NonSmall Cell Lung Cancer: Experience in Stage IIIb/IV Patients," Cancer Biology \& Therapy, Vol. 6, No. 12, 2007, pp. 1847-1852. doi:10.4161/cbt.6.12.5000

[190]F. Robert, E. M. Busby and A. F. LoBuglio, "Chemotherapy Tolerance after Radioimmunotherapy with $90 \mathrm{Y}$ CC49 Monoclonal Antibody in Patients with Advanced Non-Small Cell Lung Cancer: Clinical Effects and Hematologic Toxicity," Cancer Biotherapy and Radiopharmaceuticals, Vol. 18, No. 3, 2003, pp. 317-325. doi:10.1089/108497803322285071

[191] A. Forero-Torres, S. Shen, H. Breitz, R. B. Sims, D. B. Axworthy, M. B. Khazaeli, K.-H. Chen, I. Percent, S. Besh, A. F. LoBuglio and R. F. Meredith, "Pretargeted Radioimmunotherapy (RIT) with a Novel Anti-TAG-72 Fusion Protein," Cancer Biotherapy and Radiopharmaceuticals, Vol. 20, No. 4, 2005, pp. 379-390. doi:10.1089/cbr.2005.20.379

[192] National cancer institute, City of Hope Medical Center, "Radiolabeled Monoclonal Antibody Therapy in Treating Patients with Stage I-IIIB Non-Small Cell Lung Cancer after Completion of Radiation Therapy Alone or Combined Radiation Therapy and Chemotherapy," National Library of Medicine (US), ClinicalTrials.gov, Bethesda, 2000.

http:/clinicaltrials.gov/show/NCT00738452 NLM Identifier NCT00738452

[193] H. J. Ross, L. L. Hart, P. M. Swanson, M. U. Rarick, R. A. Figlin, A. D. Jacobs, D. E. McCune, A. H. Rosenberg, A. D. Baron, L. E. Grove, M. D. Thorn, D. M. Miller, J. G. Drachman and C. M. Rudin, "A Randomized, Multicenter Study to Determine the Safety and Efficacy of the Immunoconjugate SGN-15 plus Docetaxel for the Treatment of Non-Small Cell Lung Carcinoma," Lung Cancer, Vol. 54, No. 1, 2006, pp. 69-77. doi:10.1016/j.lungcan.2006.05.020

[194] H. Borghaei, K. Alpaugh, G. Hedlund, G. Forsberg, C. Langer, A. Rogatko, R. Hawkins, S. Dueland, U. Lassen and R. B. Cohen, "Phase I Dose Escalation, Pharmacokinetic and Pharmacodynamic Study of Naptumomab Estafenatox Alone in Patients with Advanced Cancer and with Docetaxel in Patients with Advanced Non-Small-Cell Lung Cancer," Journal of Clinical Oncology, Vol. 27, No. 25, 2009, pp. 4116-4123. doi:10.1200/JCO.2008.20.2515 